\title{
Cross-Border M\&As and Eco-Environmental Performance of European Energy Utilities
}

\author{
Evgenii Monastyrenko'
}

\begin{abstract}
European electricity industry has recently come through liberalization. Surge of intakes with high share of cross-border deals was market players' response. Measuring of post-merger performance alterations is a central question of M\&A literature. EU energy sector is responsible for significant part of global greenhouse gas emissions. Its efficiency should be regarded with respect to ecological dimension. This study addresses combined economic and environmental performance of 15 biggest European energy producers in 2005-2013. I exploit Data envelopment analysis (DEA) with $\mathrm{CO} 2$ as an undesirable output. Panel fractional regression model with financial controls is used to isolate effects of completed mergers. Results suggest that in short term firms profit from selling their subsidiaries to foreign counter-parties. This effect doesn't sustain over time. Sametype domestic deals are detrimental in short run, but performance-enhancing in long term. Domestic and cross-border acquisitions immediately damage performance. Later ones stimulate efficiency in the long run.
\end{abstract}

JEL: $\quad$ F21, G34, L25, L94, D24

Keywords: Mergers and acquisitions, Firm performance, Data envelopment analysis, Fractional regression model, Electric power industry, Carbon dioxide emissions

1 Paris School of Economics - Paris 1 Panthéon Sorbonne University. 106-112, Boulevard de l'Hôpital. 75013 Paris, France. E-mail: evgenii.monastyrenko@univ-paris1.fr. 



\title{
CROSS-BORDER M\&AS AND
}

\section{ECO-ENVIRONMENTAL PERFORMANCE OF EUROPEAN ENERGY UTILITIES}

\author{
Evgenii Monastyrenko *†
}

February 26, 2016

\begin{abstract}
European electricity industry has recently come through liberalization. Surge of intakes with high share of cross-border deals was market players' response. Measuring of post-merger performance alterations is a central question of M\&A literature. EU energy sector is responsible for significant part of global greenhouse gas emissions. Its efficiency should be regarded with respect to ecological dimension. This study addresses combined economic and environmental performance of 15 biggest European energy producers in 2005-2013. I exploit Data envelopment analysis (DEA) with CO2 as an undesirable output. Panel fractional regression model with financial controls is used to isolate effects of completed mergers. Results suggest that in short term firms profit from selling their subsidiaries to foreign counter-parties. This effect doesn't sustain over time. Same-type domestic deals are detrimental in short run, but performance-enhancing in long term. Domestic and cross-border acquisitions immediately damage performance. Later ones stimulate efficiency in the long run.
\end{abstract}

Keywords: Mergers and acquisitions, Firm performance, Data envelopment analysis, Fractional regression model, Electric power industry, Carbon dioxide emissions JEL: F21, G34, L25, L94, D24

*Paris School of Economics - Paris 1 Panthéon Sorbonne University. 106-112, Boulevard de l'Hôpital. 75013 Paris, France. E-mail: evgenii.monastyrenko@univ-paris1.fr.

${ }^{\dagger}$ Author would like to acknowledge Lionel Fontagné for support and advising. Author has greatly profited from discussions with Katrin Millock and Sandra Poncet. Special thanks go to David Thesmar for providing the access to SDC Platinum, Thomson One and BvD Orbis. Author is particularly grateful to LABEX OSE and Paris School of Economics for funding of Enerdata datasets. 
Vast and diverse empirical literature analyses outcomes of mergers and acquisitions at different levels of aggregation. Present study continues this strand by addressing causal relationship between M\&As and firm-level performance of European electricity producers. The energy sector represents particular interest due to three reasons. First, it is strongly involved in processes of mergers and acquisitions. Its share in global amount of takeovers was 6.3\% in 2001 (Pryor, 2001). In 2010 sector of power generation took second place by number of deals (Schmid et al., 2012). Second, electricity is essential for functioning of quasi-totality of manufacturing and service activities. Finally, electricity as a good is homogenous. This property eases monitoring and ensures comparability of multinationals.

Present research is focused on European electricity industry. In early 1990s the competition on this market was restricted due to numerous state interventions. Energy utilities were forced to use internal resources, instead of low-cost alternatives. In most EU members installed generation capacities have been largely overlapping actual needs. Serrallés (2006) argued that energy firms had no incentives towards efficiency. Utilities demonstrated low overall operational flexibility and did not diversify their fuel sources. In the mid-1990s European energy market has come through liberalization. Such drastic policy shift is luckily to significantly affect firm-level performance and therefore represents particular research interest.

The liberalization was initialized by First EU Energy Package (Directive 96/92/EC). Incumbents faced the risk of losing their market shares. In order to survive turbulent post-deregulation period, they started to pursue the strategy of M\&As. Haas et al. (2006) argued that the stage of vertical re-integration followed initial "value-chain disintegration". According to the report of CERNA (Codognet et al., 2002), European energy utilities completed 96 M\&As between 1998 and 2002. Mergers contributed to substantial broadening of distribution networks, which further promoted transformation of market structure.

Second EU Energy Package (Directive 2003/54/EC) has initiated the second wave of M\&As. Verde (2008) identified three principal motives of merger activity in this period. First, it is the creation of national champions, which aimed to protect internal market from hostile foreign deals. ${ }^{1}$ Second, power companies expressed growing interest to manage together gas and electricity activities. Finally, much effort was devoted to achieving vertical re-integration. Pollitt (2009) counted 549 mergers completed in the EU electricity sector in 2003-2008. He argued that M\&A activity was very significant and required specific attention from competition authorities. It is worth noting that approximately half of mergers (51.7\%) were cross-border ones. Schiavone (2012) argued that at this stage multinationals were focused on transferring novel managerial

\footnotetext{
${ }^{1}$ Another possible rational behind establishing of «national champions» is exploiting advantages of economies of scale (Considine, 2000).
} 
approaches and competencies to acquired subsidiaries. The definition of geographic market has started to evaluate from national to regional level.

Third European Union's Energy Package (Directive 2009/72/EC) further stimulated M\&A activity. In 2011 around $24 \%$ of global power deals (by targets) were completed in Europe (PricewaterhouseCoopers, 2012). Since then, this share has even grown. In 2012 and 2013 Europe held the first place among world regions with 35\% and $36 \%$, respectively (PricewaterhouseCoopers, 2014). European electric, gas and renewable firms finalized 431 and 368 deals in 2011 and 2012, respectively. It is worth noting that at this stage power utilities have been focused on diversification of their activities. Large multinationals attempt to preserve cashflow and margins on developed markets. At the same time, they continue expansion on growing markets. PricewaterhouseCoopers (2013b) revealed particular interest that is directed at targets in Southern and Eastern Europe.

Present research accounts for 165 mergers and acquisitions finalized between 2005 and 2013. This period corresponds to second and third stages of the EU electricity market's liberalization. I restrict the analysis to M\&As with targets that operate in closely related to energy generation industries. More than half of them (98 deals) fall into cross-border category. The totality of mergers in the sample is completed by 15 biggest European energy utilities. In 2013 their share in total EU electricity production reached $62.3 \%$. All of them are large multinationals combining fossil, nuclear and renewable sources in electricity generation.

The majority of existing M\&As studies devoted to energy sector addresses postmerger variation in shareholder wealth. This research aims to assess impact of mergers on real production efficiency of acquirers and vendors. For the sake of simplicity, I further call acquiring firms as "buyers". Energy utilities that sell their branches or producing units are referred as "sellers". It is worth noting that targets are excluded from the analysis due to unavailability of the data on small-sized market players. I employ Data envelopment analysis (DEA), which is a common method of entire sector's performance evaluation. This nonparametric mathematical technique is most frequently applied to financial sectors, mainly banking and insurance. Present study fits the minor segment of DEA efficiency literature on non-financial industries.

In 2013 Europe hosted $19.1 \%$ of worldwide installed capacities and produced $16.4 \%$ of the global amount of electricity. It is third, after Asia and North America, most important energy market. In 2013 the sector of public electricity and heat production was responsible for around $26.2 \%$ of total EU15 greenhouse gasses. Corresponding share in EU28 is 28.9\% (European Environment Agency, 2014). Domanico (2007) noticed that the need to account for ecological impact of production triggers constant technological developments in the industry. Performance and structure of power market should be influenced by environmental issues. In order to account the ecological aspect of elec- 
tricity production, I employ output-oriented DEA model with Carbon-dioxide (CO2) emissions as an undesirable outcome. Therefore, this study takes into account which is an advance comparing to previous studies.

Second-stage regression analysis aims to identify causal impact of M\&As on firmlevel performance. I make use of fractional regression approach, which is the most appropriate way to explain variation in relative performance scores. It is a methodological advance upon majority of extant two-stage DEA studies employing OLS approach. Results suggest that European energy utilities profit from short-run increase in their performance after international sell-off. This effect is not significant in long-run. If energy producers sell their subsidiaries to domestic rivals, they immediately lose in efficiency. Meanwhile, domestic sell-offs are beneficial in long term due to achievement of more efficient allocation of production capacities. Both domestic and cross-border acquisitions are detrimental in short run. Bidders need to deal with incoming inefficiency brought by newly acquired under-performing entities ("lemons"). Cross-border intakes increase efficiency one and two years after their completion. "Lemons" evolve to over-performing "cherries". However, this does not happen in case of domestic acquisitions.

Present research contributes to the general debate on post-merger performance alteration. Employed comprehensive two-stage approach brings this study to the border line of M\&A literature. Most of previous studies were focused on U.S. energy producers. Only two extant researches (Bednarczyk et al., 2010; Datta et al., 2013) are devoted to European energy producers. This research is an advance upon them since it addresses later stages of EU market's liberalization. Furthermore, insights on postmerger performance outcomes have more of policy interest than the ones on shareholder wealth alteration.

The rest of the paper is organized as follows. In Section 1 I summarize existing studies on post-merger performance outcomes in electricity sector. Their results are compared to general M\&As literature. I underline specificities of cross-border deals. The literature review is continued with the survey of studies on the causal relationship between M\&As and firm-level performance of energy utilities. It allows to place present research among narrow closely related literature. In Section 2 I present construction of dataset and sources. The research strategy is described in Section 3. First, I explain application of output-oriented Data envelopment analysis. Discussion of second-stage empirical strategy follows. Results are reported and interpreted in Section 4. Finally, Section 5 summarizes this research. 


\section{Literature review}

Broad and heterogeneous empirical literature on outcomes of mergers and acquisitions has been developed since 1980s. Firm-level performance changes have been systematically proxied by alterations in wealth of shareholders. General cross-industry empirical results suggest that targets gain after the merger (e.g. Asquith and Kim, 1982; Andrade et al., 2001; Bruner, 2004; Corrado, 2011). However, the outcomes in terms of an acquirer's shareholder wealth are at best not significant (e.g. Asquith, 1983; Agrawal et al., 1992; Loderer and Martin, 1992), but often negative (e.g. Moeller et al., 2004; King et al., 2004)

Cross-border mergers and acquisitions are an important instrument of international diversification (Shimizu et al., 2004). Nocke and Yeaple (2007) developed a general equilibrium framework where firms choose between exporting, greenfield FDI and cross-border M\&As. They argued that mergers and acquisitions are caused by the heterogeneity in firms' intangible assets or «capabilities». Cross-border M\&As are motivated by complementarities between internationally mobile and non-mobile capabilities. Therefore, deals of this type provide access to country-specific capabilities of target firm, which could induce positive returns.

International mergers could be beneficial for merging firms due to several reasons. Cross-border deals allow exploiting differences in tax systems and absorbing rents from market inefficiencies (Servaes and Zenner, 1994). Spillovers of corporate governance standards could improve corporate governance (Martynova and Renneboog, 2008). Shimizu et al. (2004) found that national cultural differences and organizational learning induce post-merger value creation. (Kiymaz and Mukherjee, 2000) argued that an acquirer is more able to make use of its strategic advantages during the international acquisition. Targets could benefit due to optimization of their business processes under foreign control and gaining access to cheaper external resources.

Early empirical studies on outcomes of cross-border deals contradict to general M\&A literature. They revealed that bidders gain in shareholder value (e.g. Kang, 1993; Morck and Yeung, 1992; Markides and Ittner, 1994; Cakici et al., 1996). Recent literature reported mixed evidence. Part of the studies concluded about post-merger losses in bidders' value (e.g. Eckbo and Thorburn, 2000; Denis et al., 2002; Aw and Chatterjee, 2004; Moeller et al., 2005; Aybar and Ficici, 2009; Chen and Young, 2010). Opposite results are obtained e.g. by Akhigbe and Martin (2000), Boateng et al. (2008), Francis et al. (2008), Gubbi et al. (2010) and Bhagat et al. (2011).

The majority of existing studies on M\&As in energy sector made use of event study methodology. Their results are in line with existing findings for other industries. Target's shareholders benefit from mergers, whereas the ones of acquirer lose (e.g. Ray and Thompson, 1990; Leggio and Lien, 2000). Becher et al. (2012) applied event study 
analysis to the sample of 384 mergers between U.S. electric and gas firms. They revealed that combined utilities gain in their value.

However, post-merger fluctuations in shareholder wealth of energy firms differ from the ones in other sectors. Bartunek et al. (1993) found that post-mergers gains of utilities are lower and losses are higher. Their explanation is twofold. First, acquisition of potentially most profitable targets could be prohibited because of national interests. Second, acquiring utilities could suffer from the lack of previous merging experience. For example, bidder could have no sufficient ability to negotiate for a reasonable price. Furthermore, efficient integration at operating level could be not accomplished due to the absence of such practical experience.

Leggio and Lien (2000) investigated outcomes of 76 US energy deals between 1983 and 1996. They found that in short-run mergers in energy sector are more detrimental for the wealth of acquirers, comparing to deals in non-regulated sectors. They pointed to features of the regulation of US utility sectors, which is based on the rate of return. Authorities could subtract a part of acquirer's gain and reallocate it to consumers.

McLaughlin and Mehran (1995) also highlighted the regulation as an important determinant of post-merger outcomes. They employed the sample of hostile offers on US electricity market between 1960 and 1990. Even rejected M\&As were found to positively affect short-run target utilities' shareholder returns. Meanwhile, corresponding effect for non-regulated industries is substantially higher.

Berry (2000) made the first attempt to differentiate between outcomes of crossborder and domestic mergers in energy sector. He applied standard event methodology to the sample of $21 \mathrm{M} \& A$ s involving U.S. bidders. He revealed that target's shareholder wealth increases in any case. Post-merger evolution of acquirer's shareholder value depends on the type of merger. U.S. energy utilities experienced decrease in their shareholder value if they were acquiring domestically. They are more familiar with national market and legislation, comparing to the firms that acquire foreign targets. Therefore, domestic bidders are more prone to pay nominated deal's premium.

There are only two, to my knowledge, studies on firm-level performance outcomes of M\&As in European electricity industry. Both of them are devoted to initial stage of common market's creation. The first one is Bednarczyk et al. (2010). They addressed 37 mergers and acquisitions announced between 1995 and 2005 with targets from Central and Eastern Europe. Exclusively completed cross-border mergers with bidder from a Western industrialized country are studied. Event study approach allowed to document small but significant short-run positive effect on targets shareholder wealth. Horizontal acquisitions are found to be more beneficial than vertical or diversifying ones.

Datta et al. (2013) studied 156 mergers completed in 1990-2006 between electricity, gas, water and telecommunication EU firms. A target's shareholder wealth is 6-7 
percent higher in post-merger short-term period. The same benefit in non-regulated sectors is 20-30 percent. Acquirers lose in the short term 0.1-0.2 percent of their shareholder value, which is less than in non-utility sectors. This result matches evidence from U.S. electricity industry (Leggio and Lien, 2000; Becker-Blease et al., 2008). However, combined European utilities experience statistically significant long-term losses. It could be explained by the lack of previous experience of integration. Furthermore, there are dissimilarities between EU and U.S. in terms of regulation.

Most part of studies on M\&As in energy industry explain variation in shareholder value. Becker-Blease et al. (2008) is a study that belongs to narrow branch treating performance outcomes. They examined post-merger changes in return on assets, sales to total employees, asset turnover and expense ratio, as well as stock prices of U.S. electric utilities. They concluded that merged energy companies performed no better or worse than the ones not involved in M\&A activity. They interpreted such result in a way that expected synergetic efficiency gains are absorbed by other industry stakeholders. They found that integration with gas activities or diversification into new geographic areas are detrimental for both market and operating performances.

Bagdadioglu et al. (2007) studied potential efficiency outcomes of Turkish electricity market's consolidation in 2005. They constructed DEA model allowing to predict potential merger gains, which are conditional on sufficient and appropriate incentives. It was applied to the sample consisting of 82 Turkish electricity distributors in 19992003. There are 5 inputs (number of employees, number of transformers, transformer capacity, network length and network losses) and 3 outputs (numbers of customers, electricity consumed, service area). Post-merger reduction of required inputs is estimated to achieve up to $16 \%$. This prediction was ex-post confirmed by Çelen (2013) with stochastic frontier analysis (SFA). They revealed that positive effect of mergers on performance decreases with higher proportion of sales to residential customers.

The study that is the closest methodologically to this research is Kwoka and Pollitt (2010). They accessed performance outcomes of M\&As in U.S. electricity market between 1994 and 2003. They applied Data envelopment analysis to measure efficiency of both merging and non-merging firms. Operating and total controllable expenditures are taken as inputs, while number of customers, total output and length of distribution lines are outputs. They didn't find any evidence in favor of the hypothesis that M\&As lead to better acquirer's cost performance. Target firms perform better prior to the deal, but they lose in the efficiency afterwards. These results are in line with findings of Becker-Blease et al. (2008). 


\section{The data}

Present research is conducted basing on the panel of 15 European energy producers in 2005-2013. Their complete list is reported in Table 5. In 2005 utilities of interest disposed $54.2 \%$ of installed EU capacities and produced $55.1 \%$ of total electricity. In 2013 they generated $62.3 \%$ of European energy with $53.2 \%$ of region's capacities. Data on installed capacities, power generation, $\mathrm{CO} 2$ emissions and electricity sales are extracted from Energy Utilities Watch and Power Plant Tracker databases. ${ }^{2}$ Some missing observations for years 2005-2006 and 2009-2013 are filled with annual corporate reports. In some cases the data on $\mathrm{CO} 2$ emissions and energy production is complemented with PricewaterhouseCoopers (2013a).

Data on mergers and acquisitions is extracted from Thomson Reuters SDC Platinum. ${ }^{3}$ In order to be included in the present analysis, deals must simultaneously fit following conditions. First, the deal must be fully completed between years 2004 and 2013. Second, the initial acquirer's stake of shares must be below $50 \%$, whereas it must possess $50 \%$ or more after the completion of the deal. Third, M\&As are limited to ones involving targets operating in closely related to energy production sectors. Details on targets' primary sectors are reported in Table 1.

Table 1: Repartition of targets by sectors

\begin{tabular}{llc}
\hline \hline U.S. SIC & Sector of activity & $\begin{array}{c}\text { Number } \\
\text { of firms }\end{array}$ \\
\hline 4911 & Electric services & 151 \\
4922 & Natural gas transmission & 4 \\
4923 & Natural gas transmission and distribution & 2 \\
4924 & Natural gas distribution & 1 \\
4931 & Electric and other services combined & 1 \\
4939 & Combination utilities, not elsewhere classified & 1 \\
3433 & Heating equipment, except electric and warm air furnaces & 1 \\
3511 & Steam, gas, and hydraulic turbines, and turbine generator & 3 \\
& set units & 1 \\
\hline 3621 & Motors and generators & \\
\hline
\end{tabular}

Notes: Table reports primary sectors of target firms' activities.

The deal is classified as a cross-border one if nations of target and acquirer are not

\footnotetext{
${ }^{2}$ These datasets are developed by Enerdata, an independent research and consulting agency. Author would like to thank LABEX OSE and Paris School of Economics for funding the access.

${ }^{3}$ Author would like to thank David Thesmar for providing the access to SDC Platinum and Thomson One by Thomson Reuters and Orbis by Bureau van Dijk.
} 
identical. The sample is composed of 165 deals, of which 98 cross-border (59.4\%). In some cases firms of interest finalized both cross-border and domestic deals during the same year. Firms are either buyers or sellers. There are 103 acquisitions (62.4\%). There are some cases where utilities were both buyers and sellers in different M\&As during the same year. The repartition of deals is represented in Figure 1. It is worth noting that exclusively intakes and offtakes realized by parent companies in the sample are studied.

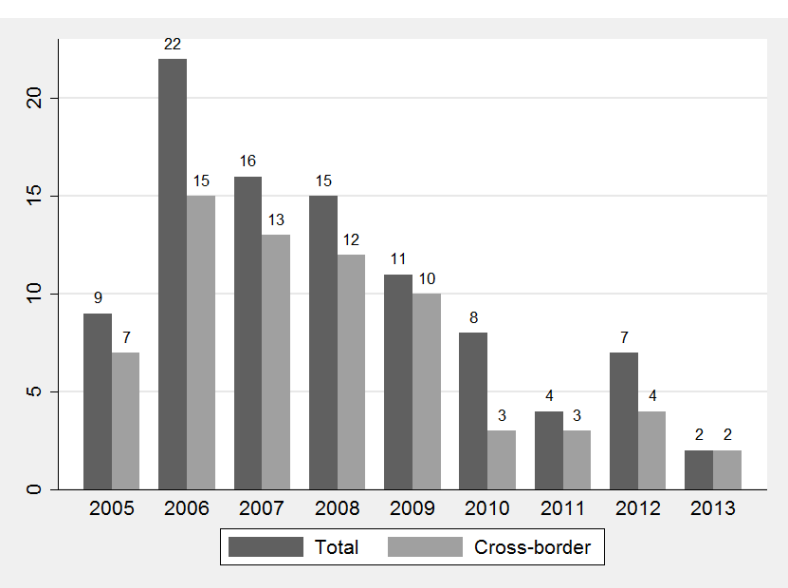

(1.1) Acquisitions

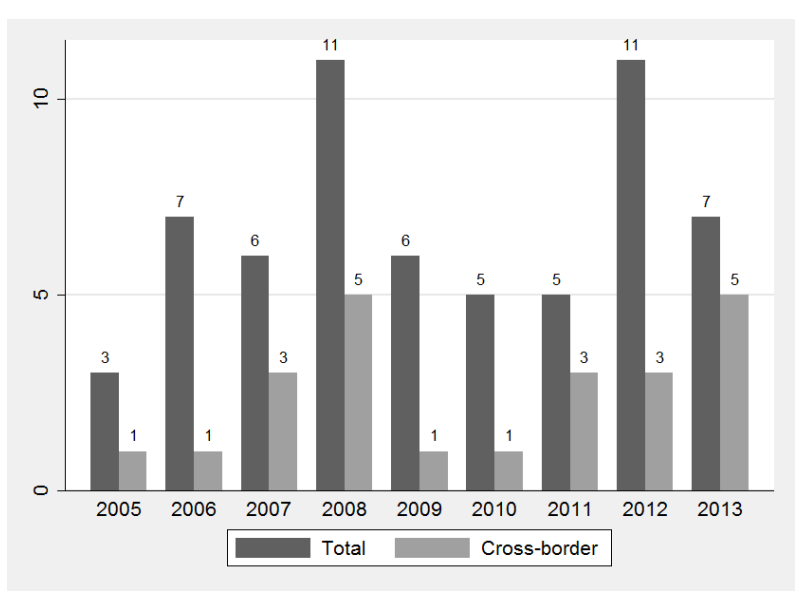

(1.2) Offtakes

Figure 1: Repartition of M\&As by years

Sources of data and definitions are summarized in Table 4. Section 6 is dedicated to descriptive statistics. Some parameters of distributions of DEA components and control variables are in Table A1. Three utilities had chosen to report their financial highlights in currency other than euro. More precisely, CEZ A.S. uses Czech crowns, E.ON SE uses U.S. dollars, and Vattenfall AB applies Swedish crowns. I convert with year-averaged exchange rates calculated by European Central Bank.

\section{Research strategy}

This research employs two-stage Data envelopment analysis (DEA). It is a nonparametric technique that employs observed inputs and outputs of decision making units (DMU) (Charnes et al., 1978). Present research is based on 2-by-2 input-output matrix. Total operating expenditures and installed production capacities are taken as inputs. Physical amounts of generated energy are regarded as target output. Carbon dioxide emissions are undesirable production output. I calculate emissions as amounts of CO2 per MWh produced. Relative nature of this measure allows bypassing inseparability of emissions from production. Absolute level of $\mathrm{CO} 2$ increases with bigger quantities produced. Meanwhile, carbon factor depends also on the share of clean capacities in use. 
I exploit undesirable measure model following Seiford and Zhu (2002). More precisely, the model is output-oriented. DMUs stick to given amounts of inputs and maximize desirable output with simultaneous minimization of undesirable one. Each firm repeats this optimization program each year.

Basing on decisions of all utilities during the entire period (2005-2013), I construct best-practice frontier. Such approach is equivalent to window analysis (Charnes et al., 1994) with the width of window equal to 9 years. This means that the technological frontier doesn't vary over period of interest. It is a realistic assumption because the usual lifetime of an energy producing plant exceeds by much 9 year-term. Indeed, there were no drastic technological changes since almost all plants operating in 2005 were kept until 2013.

Relative performance score is assigned to each firm according to its distance from efficiency frontier. Its values belong to $(0 ; 1]$. A firm has the unity score in a given year if in this year it is most efficient comparing to all other utilities over 9-year period. Values below 1 indicate utility's inefficiency in a given year.

Data envelopment analysis is a frequently applied mathematical method of an industry's performance assessment. This research exploits two-stage DEA approach, which allows to reveal causal influence of firm-specific factors on performance. (Yang and Pollitt, 2009) revealed a number of advantages of this method. First, it doesn't require strong prior judgment on the direction of independent variables' influence on performance. Second, both categorical and continuous variables could be included without the need to increase the sample size. Finally, it is relatively easy to apply and interpret, comparing to three or four-stage models.

However, DEA approach has two potential weaknesses, which are considered in present research. First, the impact of independent variables may be biased if fist-stage variables are highly correlated with second-stage controls. Therefore, I account for correlation between employed variables. Second, calculated at first stage relative performance scores lie in the interval of $(0 ; 1]$. Ramalho et al. (2011) noted that linear estimation models are not pertinent for explaining the variation of proportional or fractional response variables. They would produce predicted efficiency scores outside the unity interval (Yang and Pollitt, 2009).

I follow often referenced "quasi-Poisson" approach of Papke and Wooldridge (2008) for balanced panel dataset. Bernoulli log-likelihood model is estimated with generalized estimating equation (GEE) method. The correlation matrix between observations is set to be exchangeable. This assumption means that performance scores of the same utility at different years are equally correlated, but no correlation is allowed between firms. Such correlation structure is relevant to the relative nature of DEA scores. They are obtained by comparing all firms to the potential technological frontier. Therefore, correlation between performances of two different firms in different points of time is 
unlikely. Two alternative link functions, namely logit and probit, are used separately. It is worth noting that the logit link function is most frequently applied in the context of fractional response variables.

All estimated regression models could be represented in following general form:

$$
\begin{aligned}
\text { DEAscores }_{i t}= & \alpha_{0}+\alpha_{k} \text { M\&Adummies }_{i t}+\beta_{1} \text { Two Mergers }_{i t}+\beta_{2} \text { Two CBMergers }_{i t}+ \\
& +\beta_{3} \text { GenToSales }_{i t}+\gamma_{1} K / S_{i t}+\gamma_{2} K / S_{i t}^{2}+\gamma_{3} I / K_{i t}+\gamma_{4} Y / S_{i t}+ \\
& +\gamma_{5} \text { Leverage }_{i t}+\gamma_{6} \text { Leverage }_{i t}^{2}+\gamma_{7} \text { CurrentRatio }_{i t}+\gamma_{8} \text { CurrentRatio }_{i t}^{2}+ \\
& +\Sigma \theta_{m} \text { CapacityByCountry }_{i t}+\Sigma_{2005}^{2013} \delta_{t} Y_{\text {Cear }}+\varepsilon_{i t}
\end{aligned}
$$

Coefficients of interests are $\alpha_{k}$. They correspond to categorical dummies, so that different types of M\&A activities are distinguished. I report exact definitions of categories in Table 2 below. Impact of each of them is tested separately. All specifications include the same set of control variables.

Table 2: Variables of interest

\begin{tabular}{llcc}
\hline \hline \multirow{2}{*}{ Variables } & Definitions & \multicolumn{2}{c}{ Number of deals } \\
\cline { 3 - 4 } & & $\begin{array}{c}\text { Category } \\
\text { of interest }\end{array}$ & Baseline \\
\hline Merger & merging utilities & 77 & 58 \\
CB merger & utilities that engage in cross-border deals & 54 & 81 \\
Dom. merger & domestically merging firms & 42 & 93 \\
Buyer & acquiring utilities & 52 & 83 \\
CB buyer & utilities engaging in cross-border acquisitions & 41 & 94 \\
Dom. buyer & utilities engaging in domestic acquisitions & 19 & 116 \\
Seller & firms that sell their subsidiary & 41 & 94 \\
CB seller & utilities that sell their subsidiaries to foreign acquirers & 18 & 117 \\
Dom. seller & utilities that sell their subsidiaries domestically & 28 & 107 \\
\hline
\end{tabular}

Notes: Table reports definitions of variables of interest and sizes of corresponding categories. Numbers are given for period $t$. There are 135 observations in total.

Firms that recently came through another merger could be better able to adjust their structure and management in post-merger period. For example, they could quicker adapt their production in accordance with new fuel mix. One could refer to a merger experience. Unexperienced acquirers could lack the ability to negotiate for beneficial price. I control for it with TwoMergers dummy, which is equal to one if a firm was engaged in any M\&As during two consecutive years.

Cross-border merger experience should be different from domestic one. Energy utilities face the need to integrate entities that are functioning in another regulatory environment and under different macroeconomic conditions. An energy utility, which has already engaged human and financial resources in cross-border re-adjustments, 
is expected to be more vulnerable facing another merger the next year. I introduce TwoCBMergers that takes the unity value if the utility underwent international mergers both this year and one year ago.

Kwoka and Pollitt (2010) revealed large cost savings resulting from coordination between energy generation and distribution. Kwoka and Pollitt (2010) confirmed this result and showed that vertical integration positively influences overall performance of energy utility. I control for vertical integration by introducing GenToSales variable. It is the share of distribution output generated by the utility itself.

A firm's performance is largely influenced by its management. Vast literature ${ }^{4}$ was devoted to the study of principal-agent problem. Top management (agents) could take decisions that diverge from objectives of principals, but are beneficial for their own wealth. In that case firm could largely underperform. The risk to face principal-agent issue is higher if managers possess corporate shares. Overcoming of informational asymmetry between involved parties is a potential solution. Physical assets could be relatively easily observed and monitored. Therefore, the more a firm uses hard capital, the less it is exposed to principal-agent issue. I present study I control for capital-to sales ratio $(\mathrm{K} / \mathrm{S})$. It is computed by dividing long term tangible assets (property, plant, and equipment) by net sales. Therefore, it is a proxy of the vulnerability to principalagent problem.

Physical capital is the key production factor for the electricity industry. Energy utilities make intensive capital investments in two cases. The first one correspond to the construction of new capacities with large costs of implementation. Alternatively, production capacities could be replaced or renovated in order to fit the ecological norms. Such alterations are expected to largely influence performance of energy utilities. In present research I control for the ratio of capital expenditures to tangible long term assets (I/K) as in Himmelberg et al. (1999). They argued that firms with higher investment rate have more opportunities to implement discretionary projects and therefore grow faster.

Inelastic nature and seasonality of energy demand are important particularities of electricity market. They provide to wide range of electricity utilities, including smallscaled ones, large opportunities to exploit their market power. Energy firms might use two mechanisms of the control over energy prices (Helman, 2006). The first one is "physical withholding», which consists in generating quantities of energy below productive capacity. The alternative is to employ "financial withholding» by setting the excessive price. Therefore, the market power is expected to influence firm-level performance, which depends on production capacities in use, as well on generated electricity. In present research I follow Himmelberg et al. (1999) and control for the ratio of operating income to net sales $(\mathrm{Y} / \mathrm{S})$.

\footnotetext{
${ }^{4}$ see e.g. seminal paper of Jose et al. (1996)
} 
Leverage is an important measure of financial sustainability. It reflects the extent to which firm's activities are financed by creditor funds. Trade-off theory of optimal capital structure describes the choice of leverage as the equilibrium between benefits and costs of debt (see e.g. Kraus and Litzenberger (1973)). Performance of low-leveraged firms is a positive function of debt-to-capital ratio due to overcoming of agency problem. The performance of high-leveraged firms deteriorates with more leverage due to two reasons. First, they have fewer incentives to further invest in capital. Second, serving of their debt requires excessive cash flow (Coricelli et al., 2012). Following the intuition above, the leverage and its square term are controlled for. I apply its most referenced definition, which is the ratio of total liabilities to shareholders' equity.

Firm's daily activities require sufficient level of working capital. It is equal to the amount of cash resources immediately available to cover current debts and other obligations. This indicator is often referred to as liquidity. Wang (2002) argued that there is a tradeoff between liquidity and operating performance.

On the one hand, firms with more liquidity are more protected against the risk of default. Some of empirical studies, e.g. Jose et al. (1996), Wang (2002), García-Teruel and Martínez-Solano (2007), revealed that profitability increases with lower investment in working capital. On the other hand, if the level of working capital is reduced too much, the firm loses its ability to adjust the level of sales in accordance with actual market situation (see e.g. Wang (2002)).

I this study I control for current ratio, that is computed as the ratio of current assets to current liabilities. Baños-Caballero et al. (2012) found inverted U-shaped relationship between liquidity and profitability of small and medium-sized enterprises (SME).

Aktas et al. (2015) argued that expected relation between working capital and firm performance is negative at high level of liquidity and positive at its low level. Therefore, in present research current ratio is introduced as right-hand side variable in both linear and quadratic terms.

Functioning of energy utilities is subject of national regulation. Despite much effort dedicated by European Commission, EU members still differ a lot in terms of control over energy production. A sound example is the nuclear phase-out in Germany. Tax legislation is another source of cross-country dissimilarities. Therefore, a part of variation in performance of utilities could be attributed to their location. I account for cross-national differences by controlling for production capacities installed in Germany, France, United Kingdom, Italy, Portugal, Spain, Czech Republic and Poland. I also include variables catching capacities in Benelux and Nordic EU countries. Such aggregations are possible due to high similarities between corresponding countries.

Present paper addresses the timespan between 2005 and 2013. This period included global financial crisis. Macroeconomic conditions were different in various years before and after its start. Firm-level performance should be directly affected by macroe- 
conomics trends. Another source of year-to-year variation is the change in legislation. As an example, one could think about application of the Third European Union's Energy Package (Directive 2009/72/EC) in September 2009. This major switch in EU legislation environment should have altered energy utilities' performances. I control for unobservable time-specific factors by introducing year fixed effects.

\section{Results}

At the first stage relative performance scores are calculated basing on DEA outputoriented model with undesirable output. Their values are reported in Table 5. I represent the evolution of performance graphically on Figure 2 below.

Figure 2: Evolution of performance scores
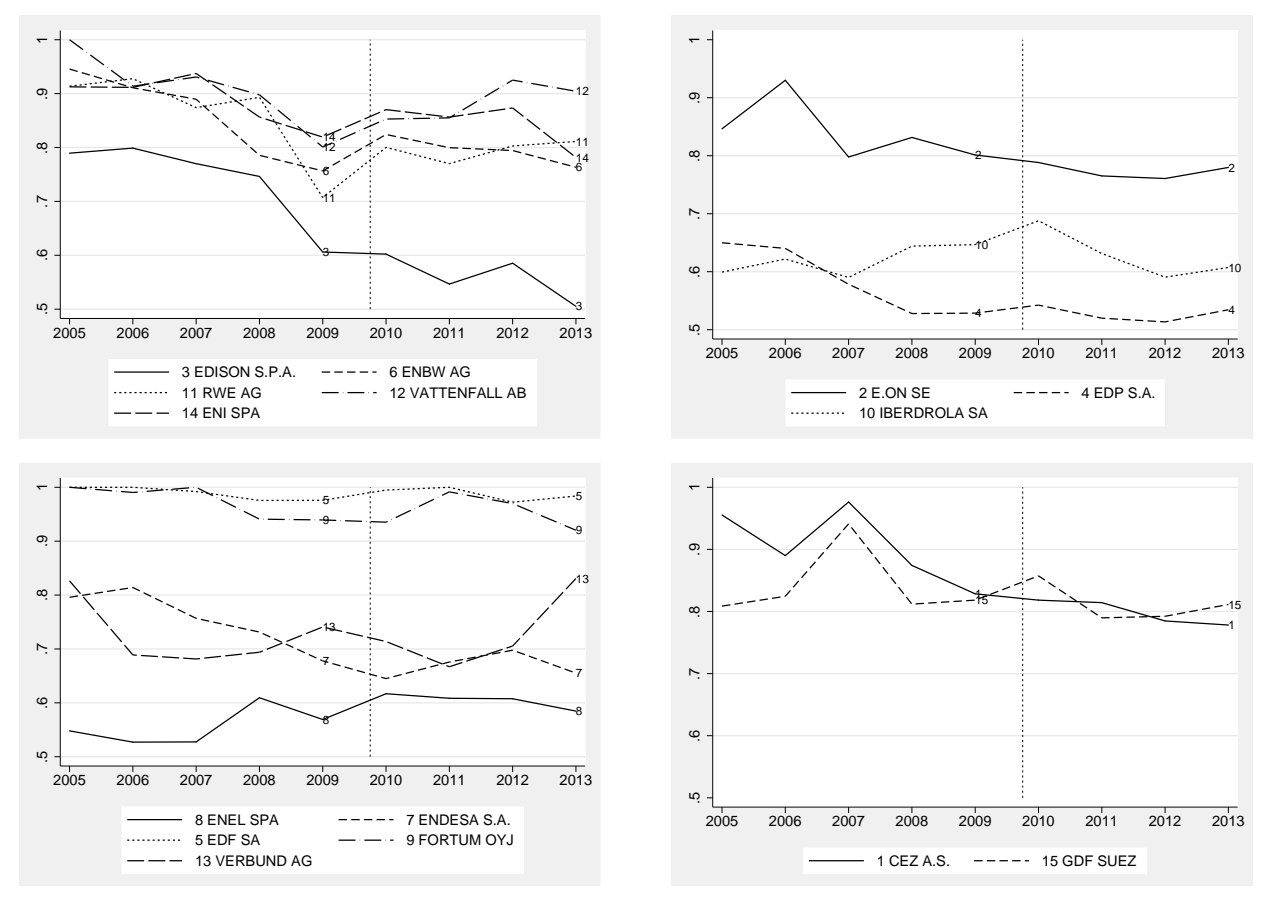

Between 2005 and 2009 individual efficiencies of energy utilities had been changing ambiguously with overall decreasing trend. One could note the rise in performance in 2010. This local growth might be caused by adoption in September 2009 of Third European Union's Energy Package (Directive 2009/72/EC). It is further advance towards common European market.

I use second-stage regression analysis in order to check for causal relation between EU energy utilities and their M\&A activity. Simar and Wilson (2007) argued that twostage DEA approach could be biased in case of high correlations between fist-stage input-output variables and second-stage controls. The actual correlation matrix is reported in Table A2. It is worth noting that the absolute value of correlation with DEA 
components don't exceed 0.55. Therefore, all of controls are appropriate. Distribution of performance with respect to main control variables is represented on boxplots in Figure 3.

Core regression analysis is devoted to estimate Equation (1). First, I address outcome of mergers completed in the year when performance is measured (period $t$ ). Meanwhile, delayed-in-time effect of deals is highly probable. Therefore, I separately regress performance scores on lagged with 1 and 2 years M\&A dummies. Detailed results are reported in Tables 6 to 10. In each table estimations with both logit (odd columns) and probit (even columns) link functions are showen. In every regression I control for year fixed effects, as well as for location of production capacities. I summarize signs and significance of obtained coefficients of interest in Table 3 below.

Table 3: Summarized results

\begin{tabular}{lccc}
\hline \hline \multirow{2}{*}{ Variables of interest } & \multicolumn{3}{c}{ Period of completion } \\
\cline { 2 - 4 } & $\mathbf{t}$ & $\mathbf{t}-\mathbf{1}$ & $\mathbf{t}-\mathbf{2}$ \\
\hline Merger & $-{ }^{* *}$ & & $+^{* *}$ \\
CB merger & $-^{*}$ & $+^{*}$ & \\
Dom. merger & $-* *$ & & $+^{* *} / * *$ \\
Buyer & $-{ }^{* *}$ & & $+^{*}$ \\
CB buyer & $-^{* *}$ & $+^{* *}$ & $+^{*}$ \\
Dom. buyer & $-^{* *}$ & & $+^{* *}$ \\
Seller & & & \\
CB seller & $+^{* * *}$ & & $+^{* * *}$ \\
Dom. seller & $-{ }^{* *}$ & & 120 \\
\hline $\mathrm{N}$ & 135 & 135 & \\
\hline
\end{tabular}

Notes: Table represents results of assessing M\&A dummies of interest over three periods. If a coefficient is statistically significant, its sign is reported. ${ }^{*}, * *$ and ${ }^{* * *}$ indicate significance at the 10,5 and 1 percent levels.

Following discussion is based on the concept that targets are typically underperforming firms ("lemons"). ${ }^{5}$ Blonigen et al. (2014) showed that targets are bought when their price is relatively low, which takes place after a negative productivity shock. They pointed that in later period "lemons" evolve to well-performing "cherries". Assuming that acquired utilities are "lemons", two simultaneous effects should take place. On the one side, acquirers have to overcome incoming inefficiency in short and mediumterm run. On the other side, vendors would be expected to strengthen their efficiency as long as they get rid of non-efficient entities.

\footnotetext{
${ }^{5}$ Some theoretical studies, e.g. Manne (1965) and Jensen and Ruback (1983) predicted selection of badly performing firms as targets for M\&As. Recent models by Nocke and Yeaple (2007) and Neary (2007) also supported this hypothesis. Lichtenberg et al. (1987) were first to prove it empirically. McGuckin and Nguyen (1995) argued that large inefficient plants are more likely to be bought than closed. Balsvik and Haller (2010) revealed that a drop in total factor productivity precedes acquisitions.
} 
A merger in broad sense immediately deteriorates performance of energy utility (Columns 1 and 2 in Table 6). Coefficient of interest is significant at 5\% level. Negative short-run effect could indicate that the deterioration of acquirer's performance dominates over vendors' efficiency gains. This effect doesn't sustain in one-year term (Columns 3 and 4). Mergers, which were completed two years ago, positively contribute to performance (Columns 5 and 6). Over two-year horizon previously underperforming entities "lemons" turn to be over-performing "cherries".

However, such hypothesis sustains only under assumption that targets systematically underperform prior to merger. Employed dataset doesn't allow computing targets' performance. Therefore, mentioned channel should be seen as only one of plausible explanations. Further in-depth identification is needed to clearly isolate effects. I decompose M\&As into cross-border and domestic deals, as well acquisitions and selloffs.

Both domestic and cross-border deals negatively influence performance in shortrun (columns 1-2, in Table 7). One should note that domestic mergers are more detrimental. The timing of positive outcome differs. International M\&As turn to bring additional performance the year that follows completion of the merger. Domestic deals are efficiency-enhancing in two-year term. However, for further interpretation, acquisitions and sell-offs should be differentiated.

Statistically significant negative effect of undifferentiated acquisitions is observed in short-run (see columns 1-2 in Table 8a). This effects turns to be positive over twoyear horizon (columns 5-6). One could interpret such result following the reasoning of acquired "lemons", which later evolve to "cherries". However, positive long-term result is weakly significant (10\% level, only for logit link function).

In order to reveal underlying differences between cross-border and domestic acquisitions, I further oppose their impacts on performance. Detailed results are reported in Table 9. Both domestic and cross-border intakes demonstrate negative short-run effect (see columns 1-2 in Table 9a and Table 9b). Incoming inefficiencies of acquired "lemons" are stronger in case of domestic deals. Corresponding effect has greater statistical significance and magnitude. Cross-border buyers further gain in efficiency in one- and two-year terms due to the integration of "cherries" in their production structure. This doesn't happen in case of same-type domestic merger.

An often-discussed in general literature motivation for sell-off is that some producing entities are under-performing ("lemons for sale"). However, there could be industry-specific reasons. Fist, energy utilities could face overall non-optimality of production capacities' allocation in terms of e.g. proximity to clients or connection to transportation lines. Second, the composition of production "energy mix" could be such that the high share of fossil sources is detrimental to environmental efficiency.

I found that energy producers, which are selling their subsidiaries either domes- 
tically or to foreign counter-parties, profit from positive effect over two-year horizon (columns 5-6 in Table 8b). This could be interpreted such that it takes two years for energy producers to fully re-adjust their production structure. No short run post-merger alterations were found (columns 1-4). The ambiguity of this result could be attributed differences between domestic and cross-border mergers.

I further decompose sell-offs to international and domestic ones. Cross-border sellers immediately profit from the rise in their performance (Table 7a). Corresponding coefficients are significant at 5\% level for specifications with logit link function (column 1 ) and at $1 \%$ level for probit (column 2). The short-term effect could be explained by selling less efficient entities. However, cross-border merger status is no longer important one and two years later.

Positive short-term post-merger performance outcome is not observed in case of domestic sell-offs. Moreover, I revealed negative immediate impact (see columns 1-2 in Table 10a). Positive effect of selling "lemons" doesn't work while selling subsidiaries to domestic counter-parties. It could be largely mitigated by strengthening of local competitors' market positions, which detriments performance of merging utility. Domestic sellers profit from higher performance at the end of two-year term (columns 5-6). This effect could be explained by successful re-adjustment of structure and location of production capacities, which doesn't happen in case of cross-border sell-offs.

It is worth noting that positive impact of M\&As of various types is mostly observed two years after their completion. Such delay could be potentially explained by the time needed to perform internal post-merger adjustments. Utilities need to adapt managerial practices and administrative structure, so that new entity would be fully integrated. Another plausible industry-specific explanation is that certain amount of time is spent to re-shape the energy mix being involved in the production of electricity.

Interpretation of control variables could serve to understanding of energy firms' efficiency. Share of own generation in amounts of energy sold demonstrates positive impact. Indeed, vertical integration influences functioning of power industry. Linear term of CurrentRatio has positive sign, while its quadratic term is negative. Therefore, I revealed inverted U-shape relationship. Performance grows with more available free cash. Energy utilities, which are less financially constrained in short-term, are better able to adapt after the merger. Meanwhile, performance deteriorates if too much cash is extracted from production.

\section{Concluding Remarks}

Since 1990s European electricity market has undergone an intensive liberalization. Cross-border mergers and acquisitions were its principal driving force. This paper addresses the question on how surge of M\&As influenced the efficiency of energy util- 
ities. I account for late stages of liberalization, which were initiated with ratification of Second and Third European Union's Energy Packages.

Two-stage Data envelopment analysis (DEA) is employed in order to assess the performance of 15 biggest European energy producers. At first step, comprehensive efficiency scores are computed basing on 2-by-2 input-output matrix. I take as inputs total operating expenditures (TOPEX) and installed capacities, which are involved in electricity production. Yearly power generation and $\mathrm{CO} 2$ emissions are introduced as desirable and undesirable outputs, respectively. This is the first, to my knowledge, attempt in M\&A literature to address post-merger performance with respect to the environmental influence.

Panel dataset comprises the period of 2005-2013. Data on installed capacities, energy production and emissions is extracted from Enerdata's Power Plant Tracker and Energy Utilities Watch. SDC Platinum is the source of information on M\&A activity. Firm-level financial controls are taken from Orbis by Bureau van Dijk and Thomson One by Thomson Reuters.

At the first stage the output-oriented optimization program is solved for entire 9year period. At the second stage DEA performance scores are regressed with GEE population-averaged model, which accounts for their relative nature. I decompose energy deals with respect to their nature (acquisition or sell-off) and international dimension. Obtained categorical dummies are estimated in separate specifications. I control for numerous financial and non-financial intra-firm characteristics, which might affect performance.

Results suggest that biggest European energy producers face immediate post-merger performance losses. In two-years term they benefit from increased performance. However, immediate increase in performance is obtained as the result of selling subsidiaries to foreign counter-parties. This effect doesn't sustain over long run. The impact of domestic sell-offs is to some extent opposite to the one of cross-border deals. They are detrimental in short run because of post-merger strengthening of competition on local market. However, domestic sell-offs are beneficial in long term due to achievement of more efficient allocation of production capacities.

I showed that acquisitions alter efficiency in a different way. Cross-border and domestic intakes diminish firm-level performance in the short run. This is the result of acquiring under-performing producing entities. International intakes, on the contrary, increase performance in long term. Acquired foreign under-performing "lemons" evolve to "cherries", which significantly contributes to efficiency of parental energy firm.

Potential direction of further research is the investigation of post-merger outcomes for target energy utilities. A sample that would comprise small energy producers should be created for that purpose. 


\section{References}

Agrawal, Anup, Jeffrey F. Jaffe, and Gershon N. Mandelker, "The post-merger performance of acquiring firms: a re-examination of an anomaly," The Journal of Finance, 1992, 47 (4), 1605-1621.

Akhigbe, Aigbe and Anna D. Martin, "Information-signaling and competitive effects of foreign acquisitions in the US," Journal of Banking and Finance, 2000, 24 (8), 13071321.

Aktas, Nihat, Ettore Croci, and Dimitris Petmezas, "Is working capital management value-enhancing? Evidence from firm performance and investments," Journal of Corporate Finance, 2015, 30, 98-113.

Andrade, Gregor, Mark L. Mitchell, and Erik Stafford, "New evidence and perspectives on mergers," The Journal of Economic Perspectives, 2001, 15 (2), 103-120.

Asquith, Paul, "Merger bids, uncertainty, and stockholder returns," Journal of Financial Economics, 1983, 11, 51-83.

- and E. Han Kim, "The impact of merger bids on the participating firms' security holders," The Journal of Finance, 1982, 37 (5), 1209-1228.

Aw, M. S. B. and R. A. Chatterjee, "The performance of UK firms acquiring large cross-border and domestic takeover targets," Applied Financial Economics, 2004, 14 (5), 337-349.

Aybar, Bülent and Aysun Ficici, "Cross-border acquisitions and firm value: An analysis of emerging-market multinationals," Journal of International Business Studies, 2009, 40 (8), 1317-1338.

Bagdadioglu, Necmiddin, Catherine Waddams Price, and Thomas Weyman-Jones, "Measuring potential gains from mergers among electricity distribution companies in Turkey using a non-parametric model," The Energy Journal, 2007, 28 (2), 83-110.

Balsvik, Ragnhild and Stefanie A. Haller, "Lemons" or Picking "Cherries"? Domestic and Foreign Acquisitions in Norwegian Manufacturing," Scandinavian Journal of Economics, 2010, 112 (2), 361-387.

Baños-Caballero, Sonia, Pedro J. García-Teruel, and Pedro Martínez-Solano, “How does working capital management affect the profitability of Spanish SMEs?," Small Business Economics, 2012, 39 (2), 517-529.

Bartunek, Kenneth, Kenneth Jessell, and Jeff Madura, "Are acquisitions by utility firms beneficial?," Applied Economics, 1993, 25 (11), 1401-1408. 
Becher, David A., J. Harold Mulherin, and Ralph A. Walkling, "Sources of Gains in Corporate Mergers: Refined Tests from a Neglected Industry," Journal of Financial and Quantitative Analysis, 2012, 47 (01), 57-89.

Becker-Blease, John R., Lawrence G. Goldberg, and Fred R. Kaen, “Mergers and acquisitions as a response to the deregulation of the electric power industry: value creation or value destruction?," Journal of Regulatory Economics, 2008, 33 (1), 21-53.

Bednarczyk, Tomasz P., Dirk Schiereck, Hardrik N. Walter, and Handrik N. Walter, "Cross-border acquisitions and shareholder wealth: Evidence from the energy and industry in Central and Eastern Europe," Journal for East European Management Studies, 2010, pp. 106-127.

Berry, S. Keith, "Excess returns in electric utility mergers during transition to competition," Journal of Regulatory Economics, 2000, 18 (2), 175-188.

Bhagat, Sanjai, Shavin Malhotra, and PengCheng Zhu, "Emerging country crossborder acquisitions: Characteristics, acquirer returns and cross-sectional determinants," Emerging Markets Review, 2011, 12 (3), 250-271.

Blonigen, Bruce A., Lionel Fontagné, Nicholas Sly, and Farid Toubal, "Cherries for sale: The incidence and timing of cross-border M\&A," Journal of International Economics, 2014, 94 (2), 341-357.

Boateng, Agyenim, Wang Qian, and Yang Tianle, "Cross-border M\&amp;As by Chinese firms: An analysis of strategic motives and performance," Thunderbird International Business Review, 2008, 50 (4), 259-270.

Bruner, Robert F., Applied Mergers and Acquisitions, John Wiley \& Sons, April 2004.

Cakici, Nusret, Chris Hessel, and Kishore Tandon, "Foreign acquisitions in the United States: Effect on shareholder wealth of foreign acquiring firms," Journal of Banking and Finance, 1996, 20, 307-329.

Çelen, Aydın, "The effect of merger and consolidation activities on the efficiency of electricity distribution regions in Turkey," Energy Policy, 2013, 59, 674-682.

Charnes, Abraham, William W. Cooper, and Edwardo Rhodes, "Measuring the efficiency of decision making units," European journal of operational research, 1978, 2 (6), 429-444.

_ , _, and Lawrence M. Seiford, Data Envelopment Analysis: Theory, Methodology and Applications, kluwer academic publishers ed. 1994. 
Chen, Yuan Yi and Michael N. Young, "Cross-border mergers and acquisitions by Chinese listed companies: A principal-principal perspective," Asia Pacific Journal of Management, 2010, 27 (3), 523-539.

Codognet, Marc-Kévin, Jean-Michel Glachant, François Lévêque, and Marie-Anne Plagnet, "Mergers and Acquisitions in the European electricity sector," CERNA, Ecole Nationale Supérieure des Mines de Paris, 2002.

Considine, Timothy J., "Cost structures for fossil fuel-fired electric power generation," The Energy Journal, 2000, 21 (2), 83-104.

Coricelli, Fabrizio, Nigel Driffield, Sarmistha Pal, and Isabelle Roland, "When does leverage hurt productivity growth? A firm-level analysis," Journal of International Money and Finance, 2012, 31 (6), 1674-1694.

Corrado, Charles J., "Event studies: A methodology review," Accounting and Finance, 2011, 51 (1), 207-234.

Datta, Sanjukta, Devendra Kodwani, and Howard Viney, "Shareholder wealth creation following M\&A: evidence from European utility sectors," Applied Financial Economics, 2013, 23 (10), 891-900.

Denis, David J., Diane K. Denis, and Keven Yost, "Global diversification, industrial diversification, and firm value," The Journal of Finance, 2002, 57 (5), 1951-1979.

Domanico, Fabio, "Concentration in the European electricity industry: The internal market as solution?," Energy Policy, 2007, 35 (10), 5064-5076.

Eckbo, B. Espen and Karin S. Thorburn, "Gains to Bidder Firms Revisited: Domestic and Foreign Acquisitions in Canada," The Journal of Financial and Quantitative Analysis, 2000, 35 (1), 1.

European Environment Agency, "Air quality in Europe 2014 report," 2014.

Francis, Bill B., Iftekhar Hasan, and Xian Sun, "Financial market integration and the value of global diversification: Evidence for US acquirers in cross-border mergers and acquisitions," Journal of Banking E Finance, 2008, 32 (8), 1522-1540.

García-Teruel, Pedro J. and Pedro Martínez-Solano, "Effects of working capital management on SME profitability," International Journal of Managerial Finance, 2007, 3 (2), 164-177.

Gubbi, Sathyajit R, Preet S Aulakh, Sougata Ray, M B Sarkar, and Raveendra Chittoor, "Do international acquisitions by emerging-economy firms create shareholder 
value? The case of Indian firms," Journal of International Business Studies, 2010, 41 (3), 397-418.

Haas, Reinhard, Jean-Michel Glachant, Nenad Keseric, and Yannick Perez, "Competition in the continental European electricity market: despair or work in progress," Electricity market reform: an international perspective, 2006, pp. 265-316.

Helman, U, "Market power monitoring and mitigation in the US wholesale power markets," Energy, 2006, 31 (6-7), 877-904.

Himmelberg, Charles P., Glenn R. Hubbard, and Darius Palia, "Understanding the determinants of managerial ownership and the link between ownership and performance," Journal of Financial Economics, 1999, 53, 353-384.

Jensen, Michael C. and Richard S. Ruback, "The market for corporate control: The scientific evidence," Journal of Financial economics, 1983, 11 (1), 5-50.

Jose, Manuel L., Carol Lancaster, and Jerry L. Stevens, "Corporate returns and cash conversion cycles," Journal of Economics and finance, 1996, 20 (1), 33-46.

Kang, Jun-Koo, “The international market for corporate control: Mergers and acquisitions of U.S. firms by Japanese firms," Journal of Financial Economics, 1993, 34 (3), 345-371.

King, David R., Dan R. Dalton, Catherine M. Daily, and Jeffrey G. Covin, "Metaanalyses of post-acquisition performance: indications of unidentified moderators," Strategic Management Journal, 2004, 25 (2), 187-200.

Kiymaz, Halil and Tarun K. Mukherjee, "The impact of country diversification on wealth effects in cross-border mergers," The Financial Review, 2000, 35 (2), 37-58.

Kraus, Alan and Robert H. Litzenberger, "A state-preference model of optimal financial leverage," The journal of finance, 1973, 28 (4), 911-922.

Kwoka, John and Michael Pollitt, "Do mergers improve efficiency? Evidence from restructuring the US electric power sector," International Journal of Industrial Organization, 2010, 28 (6), 645-656.

Leggio, Karyl B. and Donald Lien, "Mergers in the electric utility industry in a deregulatory environment," Journal of Regulatory Economics, 2000, 17 (1), 69-85.

Lichtenberg, Frank R., Donald Siegel, Dale Jorgenson, and Edwin Mansfield, "Productivity and changes in ownership of manufacturing plants," Brookings Papers on Economic Activity, 1987, 1987 (3), 643. 
Loderer, Claudio and Kenneth Martin, "Postacquisition rerformance of acquiring firms," Financial Management, 1992, 21 (3), 69-79.

Manne, Henry G., "Mergers and the market for corporate control," Journal of Political Economy, 1965, 73 (2), 110-120.

Markides, Constantinos C. and Christopher D. Ittner, "Shareholder benefits from corporate international diversification: Evidence from U.S. international acquisitions," Journal of International Business Studies, 1994, 25 (2), 343-366.

Martynova, Marina and Luc Renneboog, "Spillover of corporate governance standards in cross-border mergers and acquisitions," Journal of Corporate Finance, 2008, 14 (3), 200-223.

McGuckin, Robert H. and Sang V. Nguyen, "On productivity and plant ownership change: new evidence from the Longitudinal Research Database," The RAND Journal of Economics, 1995, 26 (2), 257-276.

McLaughlin, Robyn M. and Hamid Mehran, "Regulation and the market for corporate control: hostile tender offers for electric and gas utilities," Journal of Regulatory Economics, 1995, 8 (2), 181-204.

Moeller, Sara B, Frederik P Schlingemann, and René M Stulz, "Firm size and the gains from acquisitions," Journal of Financial Economics, 2004, 73 (2), 201-228.

Moeller, Sara B., Frederik P. Schlingemann, and René M. Stulz, “Wealth Destruction on a Massive Scale? A Study of Acquiring-Firm Returns in the Recent Merger Wave," The Journal of Finance, 2005, 60 (2), 757-782.

Morck, Randall and Bernard Yeung, "Internalization: An event study test," Journal of International Economics, 1992, 33 (1-2), 41-56.

Neary, Peter J., "Cross-border mergers as instruments of comparative advantage," Review of Economic Studies, 2007, 74, 1229-1257.

Nocke, Volker and Stephen Yeaple, "Cross-border mergers and acquisitions vs. greenfield foreign direct investment: The role of firm heterogeneity," Journal of International Economics, 2007, 72 (2), 336-365.

Papke, Leslie E. and Jeffrey M. Wooldridge, "Panel data methods for fractional response variables with an application to test pass rates," Journal of Econometrics, 2008, $145(1-2), 121-133$.

Pollitt, Michael G., "Electricity liberalisationin in the European Union: a progress report," Electricity Policy Research Group Working Paper No. 0929, 2009. 
PricewaterhouseCoopers, “Power deals: 2012 outlook and 2011 review,” 2012.

_ , "Climate Change and Electricity: European Carbon Factor, benchmarking of CO2 emissions by Europe's largest electricity utilities," Les Cahiers du Développement Durable, November 2013, 12.

_ , “European Power \& Renewables Deals," 2013.

_ , "Power \& renewables deals: 2014 outlook and 2013 review," 2014.

Pryor, Frederic L., "Dimensions of the worldwide merger boom," Journal of Economic Issues, 2001, 35 (4), 825-840.

Ramalho, Esmeralda A., Joaquim J.S. Ramalho, and José M.R. Murteira, "Alternative estimating and testing empirical strategies for fractional regression models," Journal of Economic Surveys, 2011, 25 (1), 19-68.

Ray, Dennis J. and Howard E. Thompson, "“Fifty in five": The prospects for merger in the electric utility industry," Journal of Regulatory Economics, 1990, 2 (2), 111-128.

Schiavone, Francesco, "Mergers, acquisitions and the determinants of national competitiveness in the European electricity industry," Journal of General Management, 2012, 37 (4).

Schmid, Alexandra S., Carol M. Sánchez, and Stephen R. Goldberg, "M \& A today: Great challenges, but great opportunities," Journal of Corporate Accounting $\mathcal{E}$ Finance, 2012, 23 (2), 3-8.

Seiford, Lawrence M. and Joe Zhu, "Modeling undesirable factors in efficiency evaluation," European Journal of Operational Research, 2002, 142 (1), 16-20.

Serrallés, Roberto J., "Electric energy restructuring in the European Union: Integration, subsidiarity and the challenge of harmonization," Energy Policy, 2006, 34 (16), 2542-2551.

Servaes, Henri and Marc Zenner, "Taxes and the Returns to Foreign Acquisitions in the United States," Financial Management, 1994, 23 (4), 42-56.

Shimizu, Katsuhiko, Michael A Hitt, Deepa Vaidyanath, and Vincenzo Pisano, "Theoretical foundations of cross-border mergers and acquisitions: A review of current research and recommendations for the future," Journal of International Management, 2004, 10 (3), 307-353.

Simar, Léopold and Paul W. Wilson, "Estimation and inference in two-stage, semiparametric models of production processes," Journal of Econometrics, 2007, 136 (1), 31-64. 
Verde, Stefano, "Everybody merges with somebody-The wave of M\&As in the energy industry and the EU merger policy," Energy Policy, 2008, 36 (3), 1125-1133.

Wang, Yung-Jang, "Liquidity management, operating performance, and corporate value: evidence from Japan and Taiwan," Journal of Multinational Financial Management, 2002, 12 (2), 159-169.

Yang, Hongliang and Michael Pollitt, "Incorporating both undesirable outputs and uncontrollable variables into DEA: The performance of Chinese coal-fired power plants," European Journal of Operational Research, 2009, 197 (3), 1095-1105. 


\section{Tables and figures}

Table 4: DEA and control variables

\begin{tabular}{lll}
\hline \hline Variable & Definition & Data sources \\
\hline Panel A: DEA input-output variables & \\
\hline Capacity & Total installed capacities involved in electricity generation (MW) & Enerdata and corporate reports \\
TOPEX & Total operational expenditures of energy production $(\mathrm{M} €)$ & Thomson One \\
PowerGen & Physical amounts of generated electricity (TWh) & Enerdata and corporate reports \\
Emissions & $\mathrm{CO} 2$ emissions (gCO2 per kWh) & Enerdata, corporate reports \\
& & and PricewaterhouseCoopers \\
& & $(2013 \mathrm{a})$ \\
\hline
\end{tabular}

Panel B: Nonfinancial controls

\section{Panel C: Financial controls}

\begin{tabular}{lll}
\hline K/S & The ratio of long term tangible assets (property, plant, and equipment) to net sales & Thomson One* \\
Y/S & The ratio of operating income to net sales & Thomson One \\
I/K & The ratio of capital expenditures to tangible long term assets (property, plant, and equipment) & Thomson One* \\
Leverage & Financial leverage computed as the ratio of total liabilities to shareholders' equity & Thomson One* \\
Current ratio & The ratio of current assets to current liabilities & BvD Orbis \\
\hline
\end{tabular}

Notes: Table represents definitions and sources of employed variables. ${ }^{*}$ indicates cases where own computations were undertaken basing on the initial data. 
Table 5: DEA scores

\begin{tabular}{|c|c|c|c|c|c|c|c|c|c|c|}
\hline Firm name & Headquarter location & 2005 & 2006 & 2007 & 2008 & 2009 & 2010 & 2011 & 2012 & 2013 \\
\hline CEZ A.S. & Prague, Czech Republic & .9554 & .89 & .9763 & .8742 & .8285 & .8183 & .8143 & .7848 & .7782 \\
\hline E.ON SE & Dusseldorf, Germany & .8464 & .9301 & .7978 & .8315 & .8013 & .7883 & .7652 & .7607 & .7798 \\
\hline EDISON S.P.A. & Milan, Italy & .7895 & .7989 & .77 & .7463 & .6061 & .6022 & .5466 & .5853 & .5053 \\
\hline EDP S.A. & Lisbon, Portugal & .6499 & .6402 & .5784 & .5279 & .5286 & .5424 & .5199 & .5135 & .5344 \\
\hline EDF SA & Paris, France & 1 & 1 & .9921 & .9756 & .9758 & .9949 & 1 & .9724 & .9838 \\
\hline ENBW AG & Karlsruhe, Germany & .9456 & .9109 & .8896 & .7855 & .7566 & .8242 & .7997 & .7944 & .7634 \\
\hline ENDESA S.A. & Madrid, Spain & .7959 & .8141 & .7568 & .7314 & .6779 & .645 & .6757 & .6977 & .6552 \\
\hline ENEL SPA & Rome, Italy & .548 & .5271 & .5275 & .6095 & .5691 & .6169 & .6085 & .6076 & .5847 \\
\hline FORTUM OYJ & Espoo, Finland & .9126 & .9116 & .9374 & .8565 & .8193 & .8703 & .8564 & .8734 & .7816 \\
\hline IBERDROLA SA & Bilbao, Spain & 1 & .9904 & 1 & .9409 & .9394 & .9353 & .9915 & .9698 & .9203 \\
\hline RWE AG & Essen, Germany & .8087 & .8245 & .9411 & .8119 & .8183 & .8574 & .7898 & .7923 & .8113 \\
\hline VATTENFALL AB & Stockholm, Sweden & .5993 & .6219 & .5901 & .6441 & .6467 & .6879 & .6314 & .5906 & .6073 \\
\hline VERBUND AG & Vienna, Austria & .9137 & .9277 & .874 & .8931 & .7071 & .8002 & .77 & .8029 & .8112 \\
\hline ENI SPA & Rome, Italy & 1 & .9137 & .9309 & .8978 & .8009 & .8528 & .855 & .9251 & .9044 \\
\hline GDF SUEZ & Courbevoie, France & .8264 & .6889 & .6814 & .6939 & .7408 & .7138 & .667 & .7054 & .8307 \\
\hline
\end{tabular}

Notes: Table reports calculated DEA performance scores. A firm has the unity score in a given year if in this year it is most efficient comparing to all other utilities over 9-year period. 
Table 6: Impact of M\&As on productivity

\begin{tabular}{|c|c|c|c|c|c|c|}
\hline & $\begin{array}{c}(1) \\
\text { Logit }\end{array}$ & $\begin{array}{c}(2) \\
\text { Probit }\end{array}$ & $\begin{array}{c}(3) \\
\text { Logit }\end{array}$ & $\begin{array}{c}(4) \\
\text { Probit }\end{array}$ & $\begin{array}{c}(5) \\
\text { Logit }\end{array}$ & $\begin{array}{c}(6) \\
\text { Probit }\end{array}$ \\
\hline Merger & $\begin{array}{l}-0.13^{* *} \\
(0.054)\end{array}$ & $\begin{array}{c}-0.080^{* *} \\
(0.035)\end{array}$ & & & & \\
\hline Merger t-1 & & & $\begin{array}{c}0.020 \\
(0.048)\end{array}$ & $\begin{array}{c}0.015 \\
(0.028)\end{array}$ & & \\
\hline Merger $\mathrm{t}-2$ & & & & & $\begin{array}{l}0.12^{* *} \\
(0.056)\end{array}$ & $\begin{array}{c}0.068^{* *} \\
(0.033)\end{array}$ \\
\hline TwoMergers & $\begin{array}{l}0.13^{* *} \\
(0.068)\end{array}$ & $\begin{array}{l}0.082^{* *} \\
(0.037)\end{array}$ & $\begin{array}{c}0.0090 \\
(0.11)\end{array}$ & $\begin{array}{l}0.0089 \\
(0.058)\end{array}$ & $\begin{array}{c}0.14 \\
(0.094)\end{array}$ & $\begin{array}{c}0.079 \\
(0.055)\end{array}$ \\
\hline TwoCBMergers & $\begin{array}{c}-0.10 \\
(0.092)\end{array}$ & $\begin{array}{l}-0.062 \\
(0.053)\end{array}$ & $\begin{array}{l}-0.089 \\
(0.094)\end{array}$ & $\begin{array}{l}-0.056 \\
(0.054)\end{array}$ & $\begin{array}{l}-0.20^{*} \\
(0.11)\end{array}$ & $\begin{array}{l}-0.12^{*} \\
(0.067)\end{array}$ \\
\hline GenToSales & $\begin{array}{c}0.53 \\
(0.43)\end{array}$ & $\begin{array}{c}0.34 \\
(0.25)\end{array}$ & $\begin{array}{c}0.61 \\
(0.49)\end{array}$ & $\begin{array}{c}0.35 \\
(0.27)\end{array}$ & $\begin{array}{c}0.65 \\
(0.42)\end{array}$ & $\begin{array}{c}0.42 \\
(0.26)\end{array}$ \\
\hline $\mathrm{K} / \mathrm{S}$ & $\begin{array}{c}0.13 \\
(0.25)\end{array}$ & $\begin{array}{l}0.067 \\
(0.16)\end{array}$ & $\begin{array}{l}-0.10 \\
(0.26)\end{array}$ & $\begin{array}{l}-0.024 \\
(0.16)\end{array}$ & $\begin{array}{l}-0.24 \\
(0.29)\end{array}$ & $\begin{array}{l}-0.21 \\
(0.18)\end{array}$ \\
\hline $\mathrm{K} / \mathrm{S}$ square & $\begin{array}{c}0.076 \\
(0.076)\end{array}$ & $\begin{array}{c}0.043 \\
(0.052)\end{array}$ & $\begin{array}{c}0.13 \\
(0.081)\end{array}$ & $\begin{array}{c}0.065 \\
(0.054)\end{array}$ & $\begin{array}{c}0.14 \\
(0.090)\end{array}$ & $\begin{array}{l}0.093^{*} \\
(0.056)\end{array}$ \\
\hline $\mathrm{I} / \mathrm{K}$ & $\begin{array}{c}-1.33^{* * *} \\
(0.42)\end{array}$ & $\begin{array}{c}-0.81^{* * *} \\
(0.28)\end{array}$ & $\begin{array}{c}-1.33^{* * * *} \\
(0.49)\end{array}$ & $\begin{array}{c}-0.77^{* * *} \\
(0.28)\end{array}$ & $\begin{array}{c}-1.07^{*} \\
(0.61)\end{array}$ & $\begin{array}{c}-0.65^{*} \\
(0.38)\end{array}$ \\
\hline $\mathrm{Y} / \mathrm{S}$ & $\begin{array}{c}-1.52^{* *} \\
(0.65)\end{array}$ & $\begin{array}{c}-1.11^{* * *} \\
(0.38)\end{array}$ & $\begin{array}{l}-1.37^{*} \\
(0.75)\end{array}$ & $\begin{array}{c}-0.99^{* *} \\
(0.41)\end{array}$ & $\begin{array}{l}-1.36^{*} \\
(0.80)\end{array}$ & $\begin{array}{c}-0.97^{* *} \\
(0.47)\end{array}$ \\
\hline Leverage & $\begin{array}{l}-0.070 \\
(0.097)\end{array}$ & $\begin{array}{l}-0.033 \\
(0.057)\end{array}$ & $\begin{array}{l}-0.082 \\
(0.11)\end{array}$ & $\begin{array}{l}-0.035 \\
(0.063)\end{array}$ & $\begin{array}{l}-0.15 \\
(0.14)\end{array}$ & $\begin{array}{l}-0.076 \\
(0.082)\end{array}$ \\
\hline Leverage square & $\begin{array}{c}0.0080 \\
(0.0092)\end{array}$ & $\begin{array}{c}0.0039 \\
(0.0054)\end{array}$ & $\begin{array}{c}0.010 \\
(0.010)\end{array}$ & $\begin{array}{c}0.0046 \\
(0.0059)\end{array}$ & $\begin{array}{c}0.014 \\
(0.013)\end{array}$ & $\begin{array}{c}0.0064 \\
(0.0082)\end{array}$ \\
\hline CurrentRatio & $\begin{array}{l}0.77^{*} \\
(0.41)\end{array}$ & $\begin{array}{l}0.47^{*} \\
(0.25)\end{array}$ & $\begin{array}{l}0.50^{*} \\
(0.28)\end{array}$ & $\begin{array}{c}0.33 \\
(0.20)\end{array}$ & $\begin{array}{c}0.57 \\
(0.35)\end{array}$ & $\begin{array}{c}0.31 \\
(0.22)\end{array}$ \\
\hline CurrentRatio square & $\begin{array}{c}-0.32^{* *} \\
(0.14)\end{array}$ & $\begin{array}{l}-0.19^{* *} \\
(0.085)\end{array}$ & $\begin{array}{l}-0.22^{* *} \\
(0.091)\end{array}$ & $\begin{array}{l}-0.14^{* *} \\
(0.069)\end{array}$ & $\begin{array}{l}-0.22^{*} \\
(0.13)\end{array}$ & $\begin{array}{c}-0.12 \\
(0.081)\end{array}$ \\
\hline Constant & $\begin{array}{c}0.67 \\
(0.55)\end{array}$ & $\begin{array}{c}0.42 \\
(0.35)\end{array}$ & $\begin{array}{c}0.91 \\
(0.58)\end{array}$ & $\begin{array}{c}0.51 \\
(0.37)\end{array}$ & $\begin{array}{l}0.96^{*} \\
(0.57)\end{array}$ & $\begin{array}{l}0.59^{*} \\
(0.34)\end{array}$ \\
\hline Year FE & Yes & Yes & Yes & Yes & Yes & Yes \\
\hline Location controls & Yes & Yes & Yes & Yes & Yes & Yes \\
\hline Observations & 135 & 135 & 135 & 135 & 120 & 120 \\
\hline
\end{tabular}

Notes: Table reports detailed estimations of population-averaged GEE model. Dependent variable is DEA performance score. Semirobust standard errors clustered on firm-level are reported in parentheses. ${ }^{*}, * *$ and ${ }^{* * *}$ indicate significance at the 10,5 and 1 percent levels. 
Table 7a: Impact of cross-border mergers on productivity

\begin{tabular}{|c|c|c|c|c|c|c|}
\hline & $\begin{array}{l}(1) \\
\text { Logit }\end{array}$ & $\begin{array}{c}(2) \\
\text { Probit }\end{array}$ & $\begin{array}{c}(3) \\
\text { Logit }\end{array}$ & $\begin{array}{c}(4) \\
\text { Probit }\end{array}$ & $\begin{array}{l}(5) \\
\text { Logit }\end{array}$ & $\begin{array}{c}(6) \\
\text { Probit }\end{array}$ \\
\hline $\mathrm{CB}$ merger $\mathrm{t}$ & $\begin{array}{c}-0.092^{*} \\
(0.053)\end{array}$ & $\begin{array}{c}-0.056^{*} \\
(0.032)\end{array}$ & & & & \\
\hline CB merger $\mathrm{t}-1$ & & & $\begin{array}{l}0.076^{*} \\
(0.042)\end{array}$ & $\begin{array}{l}0.040^{*} \\
(0.023)\end{array}$ & & \\
\hline CB merger $\mathrm{t}-2$ & & & & & $\begin{array}{c}0.093 \\
(0.067)\end{array}$ & $\begin{array}{c}0.050 \\
(0.041)\end{array}$ \\
\hline TwoMergers & $\begin{array}{c}0.065 \\
(0.078)\end{array}$ & $\begin{array}{c}0.038 \\
(0.042)\end{array}$ & $\begin{array}{l}0.0045 \\
(0.084)\end{array}$ & $\begin{array}{c}0.011 \\
(0.046)\end{array}$ & $\begin{array}{c}0.11 \\
(0.10)\end{array}$ & $\begin{array}{c}0.061 \\
(0.058)\end{array}$ \\
\hline TwoCBMergers & $\begin{array}{l}-0.058 \\
(0.10)\end{array}$ & $\begin{array}{l}-0.035 \\
(0.060)\end{array}$ & $\begin{array}{c}-0.13 \\
(0.098)\end{array}$ & $\begin{array}{l}-0.077 \\
(0.056)\end{array}$ & $\begin{array}{l}-0.18 \\
(0.13)\end{array}$ & $\begin{array}{c}-0.098 \\
(0.074)\end{array}$ \\
\hline GenToSales & $\begin{array}{c}0.51 \\
(0.45)\end{array}$ & $\begin{array}{c}0.32 \\
(0.26)\end{array}$ & $\begin{array}{c}0.64 \\
(0.49)\end{array}$ & $\begin{array}{c}0.35 \\
(0.27)\end{array}$ & $\begin{array}{c}0.72 \\
(0.46)\end{array}$ & $\begin{array}{c}0.43 \\
(0.28)\end{array}$ \\
\hline $\mathrm{K} / \mathrm{S}$ & $\begin{array}{c}0.15 \\
(0.29)\end{array}$ & $\begin{array}{l}0.084 \\
(0.18)\end{array}$ & $\begin{array}{c}-0.12 \\
(0.27)\end{array}$ & $\begin{array}{c}-0.019 \\
(0.16)\end{array}$ & $\begin{array}{c}-0.32 \\
(0.30)\end{array}$ & $\begin{array}{l}-0.22 \\
(0.18)\end{array}$ \\
\hline $\mathrm{K} / \mathrm{S}$ square & $\begin{array}{c}0.074 \\
(0.085)\end{array}$ & $\begin{array}{c}0.040 \\
(0.057)\end{array}$ & $\begin{array}{c}0.13 \\
(0.085)\end{array}$ & $\begin{array}{c}0.062 \\
(0.057)\end{array}$ & $\begin{array}{c}0.16^{*} \\
(0.092)\end{array}$ & $\begin{array}{l}0.098^{*} \\
(0.057)\end{array}$ \\
\hline $\mathrm{I} / \mathrm{K}$ & $\begin{array}{c}-1.14^{* * *} \\
(0.41)\end{array}$ & $\begin{array}{c}-0.70^{* * *} \\
(0.26)\end{array}$ & $\begin{array}{c}-1.32^{* * *} \\
(0.50)\end{array}$ & $\begin{array}{c}-0.76^{* * *} \\
(0.28)\end{array}$ & $\begin{array}{l}-0.95 \\
(0.71)\end{array}$ & $\begin{array}{l}-0.56 \\
(0.42)\end{array}$ \\
\hline $\mathrm{Y} / \mathrm{S}$ & $\begin{array}{c}-1.33^{* *} \\
(0.66)\end{array}$ & $\begin{array}{c}-1.01^{* * *} \\
(0.38)\end{array}$ & $\begin{array}{l}-1.16 \\
(0.79)\end{array}$ & $\begin{array}{c}-0.89^{* *} \\
(0.43)\end{array}$ & $\begin{array}{l}-1.16 \\
(0.94)\end{array}$ & $\begin{array}{l}-0.85 \\
(0.54)\end{array}$ \\
\hline Leverage & $\begin{array}{l}-0.090 \\
(0.099)\end{array}$ & $\begin{array}{l}-0.043 \\
(0.059)\end{array}$ & $\begin{array}{c}-0.090 \\
(0.11)\end{array}$ & $\begin{array}{l}-0.039 \\
(0.062)\end{array}$ & $\begin{array}{l}-0.20 \\
(0.17)\end{array}$ & $\begin{array}{c}-0.099 \\
(0.10)\end{array}$ \\
\hline Leverage square & $\begin{array}{c}0.010 \\
(0.0092)\end{array}$ & $\begin{array}{c}0.0051 \\
(0.0056)\end{array}$ & $\begin{array}{c}0.011 \\
(0.0099)\end{array}$ & $\begin{array}{c}0.0051 \\
(0.0058)\end{array}$ & $\begin{array}{c}0.020 \\
(0.018)\end{array}$ & $\begin{array}{l}0.0094 \\
(0.011)\end{array}$ \\
\hline CurrentRatio & $\begin{array}{l}0.67^{*} \\
(0.35)\end{array}$ & $\begin{array}{l}0.41^{*} \\
(0.21)\end{array}$ & $\begin{array}{c}0.57^{* * *} \\
(0.20)\end{array}$ & $\begin{array}{c}0.36^{* *} \\
(0.17)\end{array}$ & $\begin{array}{c}0.40 \\
(0.35)\end{array}$ & $\begin{array}{c}0.24 \\
(0.22)\end{array}$ \\
\hline CurrentRatio square & $\begin{array}{c}-0.28^{* *} \\
(0.12)\end{array}$ & $\begin{array}{c}-0.17^{* *} \\
(0.071)\end{array}$ & $\begin{array}{c}-0.24^{* * *} \\
(0.060)\end{array}$ & $\begin{array}{c}-0.15^{* * *} \\
(0.056)\end{array}$ & $\begin{array}{c}-0.18 \\
(0.13)\end{array}$ & $\begin{array}{c}-0.10 \\
(0.078)\end{array}$ \\
\hline Constant & $\begin{array}{c}0.75 \\
(0.59)\end{array}$ & $\begin{array}{c}0.46 \\
(0.38)\end{array}$ & $\begin{array}{c}0.84 \\
(0.55)\end{array}$ & $\begin{array}{c}0.49 \\
(0.36)\end{array}$ & $\begin{array}{l}1.06^{*} \\
(0.60)\end{array}$ & $\begin{array}{l}0.65^{*} \\
(0.36)\end{array}$ \\
\hline Year FE & Yes & Yes & Yes & Yes & Yes & Yes \\
\hline Location controls & Yes & Yes & Yes & Yes & Yes & Yes \\
\hline Observations & 135 & 135 & 135 & 135 & 120 & 120 \\
\hline
\end{tabular}

Table 7b: Impact of domestic mergers on productivity

\begin{tabular}{|c|c|c|c|c|c|c|}
\hline & $\begin{array}{c}(1) \\
\text { Logit }\end{array}$ & $\begin{array}{c}(2) \\
\text { Probit }\end{array}$ & $\begin{array}{c}\text { (3) } \\
\text { Logit }\end{array}$ & $\begin{array}{c}(4) \\
\text { Probit }\end{array}$ & $\begin{array}{l}(5) \\
\text { Logit }\end{array}$ & $\begin{array}{c}(6) \\
\text { Probit }\end{array}$ \\
\hline Domestic merger $t$ & $\begin{array}{c}-0.14^{* * *} \\
(0.047)\end{array}$ & $\begin{array}{c}-0.079^{* * *} \\
(0.028)\end{array}$ & & & & \\
\hline Domestic merger $\mathrm{t}-1$ & & & $\begin{array}{l}-0.043 \\
(0.048)\end{array}$ & $\begin{array}{l}-0.024 \\
(0.027)\end{array}$ & & \\
\hline Domestic merger $\mathrm{t}-2$ & & & & & $\begin{array}{l}0.13^{* * *} \\
(0.047)\end{array}$ & $\begin{array}{c}0.072^{* *} \\
(0.029)\end{array}$ \\
\hline TwoMergers & $\begin{array}{c}0.071 \\
(0.096)\end{array}$ & $\begin{array}{c}0.047 \\
(0.050)\end{array}$ & $\begin{array}{l}0.037 \\
(0.11)\end{array}$ & $\begin{array}{c}0.026 \\
(0.060)\end{array}$ & $\begin{array}{c}0.12 \\
(0.092)\end{array}$ & $\begin{array}{c}0.074 \\
(0.053)\end{array}$ \\
\hline TwoCBMergers & $\begin{array}{l}-0.12 \\
(0.11)\end{array}$ & $\begin{array}{l}-0.070 \\
(0.059)\end{array}$ & $\begin{array}{l}-0.097 \\
(0.10)\end{array}$ & $\begin{array}{l}-0.060 \\
(0.059)\end{array}$ & $\begin{array}{c}-0.24^{* *} \\
(0.11)\end{array}$ & $\begin{array}{l}-0.14^{* *} \\
(0.066)\end{array}$ \\
\hline GenToSales & $\begin{array}{l}0.73^{*} \\
(0.44)\end{array}$ & $\begin{array}{c}0.40 \\
(0.24)\end{array}$ & $\begin{array}{c}0.61 \\
(0.49)\end{array}$ & $\begin{array}{c}0.34 \\
(0.27)\end{array}$ & $\begin{array}{c}0.86 \\
(0.53)\end{array}$ & $\begin{array}{c}0.51 \\
(0.31)\end{array}$ \\
\hline $\mathrm{K} / \mathrm{S}$ & $\begin{array}{c}-0.19 \\
(0.21)\end{array}$ & $\begin{array}{l}-0.057 \\
(0.12)\end{array}$ & $\begin{array}{c}-0.11 \\
(0.28)\end{array}$ & $\begin{array}{c}-0.029 \\
(0.16)\end{array}$ & $\begin{array}{l}-0.51 \\
(0.32)\end{array}$ & $\begin{array}{c}-0.32 \\
(0.20)\end{array}$ \\
\hline $\mathrm{K} / \mathrm{S}$ square & $\begin{array}{c}0.14^{* *} \\
(0.066)\end{array}$ & $\begin{array}{l}0.070^{*} \\
(0.043)\end{array}$ & $\begin{array}{c}0.13 \\
(0.087)\end{array}$ & $\begin{array}{c}0.066 \\
(0.056)\end{array}$ & $\begin{array}{l}0.22^{* *} \\
(0.10)\end{array}$ & $\begin{array}{c}0.13^{* *} \\
(0.062)\end{array}$ \\
\hline $\mathrm{I} / \mathrm{K}$ & $\begin{array}{c}-1.64^{* * *} \\
(0.53)\end{array}$ & $\begin{array}{c}-0.90^{* * *} \\
(0.30)\end{array}$ & $\begin{array}{c}-1.41^{* * *} \\
(0.51)\end{array}$ & $\begin{array}{c}-0.82^{* * *} \\
(0.28)\end{array}$ & $\begin{array}{l}-1.28^{*} \\
(0.76)\end{array}$ & $\begin{array}{c}-0.72^{*} \\
(0.43)\end{array}$ \\
\hline $\mathrm{Y} / \mathrm{S}$ & $\begin{array}{c}-1.56^{* *} \\
(0.71)\end{array}$ & $\begin{array}{c}-1.07^{* * *} \\
(0.38)\end{array}$ & $\begin{array}{c}-1.44^{* *} \\
(0.71)\end{array}$ & $\begin{array}{c}-1.02^{* * *} \\
(0.39)\end{array}$ & $\begin{array}{l}-1.47^{*} \\
(0.86)\end{array}$ & $\begin{array}{c}-1.00^{* *} \\
(0.49)\end{array}$ \\
\hline Leverage & $\begin{array}{l}-0.090 \\
(0.098)\end{array}$ & $\begin{array}{l}-0.042 \\
(0.054)\end{array}$ & $\begin{array}{c}-0.091 \\
(0.11)\end{array}$ & $\begin{array}{l}-0.040 \\
(0.064)\end{array}$ & $\begin{array}{c}-0.12 \\
(0.14)\end{array}$ & $\begin{array}{l}-0.055 \\
(0.081)\end{array}$ \\
\hline Leverage square & $\begin{array}{c}0.0084 \\
(0.0095)\end{array}$ & $\begin{array}{c}0.0040 \\
(0.0054)\end{array}$ & $\begin{array}{c}0.011 \\
(0.010)\end{array}$ & $\begin{array}{c}0.0051 \\
(0.0060)\end{array}$ & $\begin{array}{l}0.0097 \\
(0.015)\end{array}$ & $\begin{array}{c}0.0040 \\
(0.0087)\end{array}$ \\
\hline CurrentRatio & $\begin{array}{l}0.48^{*} \\
(0.29)\end{array}$ & $\begin{array}{c}0.30 \\
(0.19)\end{array}$ & $\begin{array}{l}0.45^{* *} \\
(0.22)\end{array}$ & $\begin{array}{l}0.30^{*} \\
(0.17)\end{array}$ & $\begin{array}{c}0.36 \\
(0.29)\end{array}$ & $\begin{array}{c}0.22 \\
(0.19)\end{array}$ \\
\hline CurrentRatio square & $\begin{array}{l}-0.23^{* *} \\
(0.093)\end{array}$ & $\begin{array}{l}-0.14^{* *} \\
(0.062)\end{array}$ & $\begin{array}{c}-0.20^{* * *} \\
(0.072)\end{array}$ & $\begin{array}{l}-0.13^{* *} \\
(0.059)\end{array}$ & $\begin{array}{c}-0.15 \\
(0.11)\end{array}$ & $\begin{array}{l}-0.087 \\
(0.069)\end{array}$ \\
\hline Constant & $\begin{array}{l}0.99^{* *} \\
(0.50) \\
\end{array}$ & $\begin{array}{l}0.57^{*} \\
(0.31) \\
\end{array}$ & $\begin{array}{l}1.01^{*} \\
(0.58) \\
\end{array}$ & $\begin{array}{c}0.57 \\
(0.37) \\
\end{array}$ & $\begin{array}{l}1.06^{*} \\
(0.60) \\
\end{array}$ & $\begin{array}{l}0.64^{*} \\
(0.36) \\
\end{array}$ \\
\hline Year FE & Yes & Yes & Yes & Yes & Yes & Yes \\
\hline Location controls & Yes & Yes & Yes & Yes & Yes & Yes \\
\hline Observations & 135 & 135 & 135 & 135 & 120 & 120 \\
\hline
\end{tabular}


Table 8a: Impact of acquisitions on productivity

\begin{tabular}{|c|c|c|c|c|c|c|}
\hline & $\begin{array}{l}(1) \\
\text { Logit }\end{array}$ & $\begin{array}{c}(2) \\
\text { Probit }\end{array}$ & $\begin{array}{c}(3) \\
\text { Logit }\end{array}$ & $\begin{array}{c}(4) \\
\text { Probit }\end{array}$ & $\begin{array}{c}(5) \\
\text { Logit }\end{array}$ & $\begin{array}{c}(6) \\
\text { Probit }\end{array}$ \\
\hline Buyer $t$ & $\begin{array}{c}-0.12^{* *} \\
(0.060)\end{array}$ & $\begin{array}{c}-0.076^{* *} \\
(0.036)\end{array}$ & & & & \\
\hline Buyer t-1 & & & $\begin{array}{c}0.079 \\
(0.055)\end{array}$ & $\begin{array}{c}0.046 \\
(0.030)\end{array}$ & & \\
\hline Buyer t-2 & & & & & $\begin{array}{l}0.098^{*} \\
(0.059)\end{array}$ & $\begin{array}{c}0.047 \\
(0.035)\end{array}$ \\
\hline TwoMergers & $\begin{array}{c}0.073 \\
(0.076)\end{array}$ & $\begin{array}{c}0.044 \\
(0.042)\end{array}$ & $\begin{array}{c}-0.0063 \\
(0.10)\end{array}$ & $\begin{array}{l}0.0036 \\
(0.055)\end{array}$ & $\begin{array}{c}0.12 \\
(0.11)\end{array}$ & $\begin{array}{c}0.064 \\
(0.062)\end{array}$ \\
\hline TwoCBMergers & $\begin{array}{l}-0.096 \\
(0.086)\end{array}$ & $\begin{array}{l}-0.057 \\
(0.049)\end{array}$ & $\begin{array}{c}-0.11 \\
(0.086)\end{array}$ & $\begin{array}{l}-0.069 \\
(0.050)\end{array}$ & $\begin{array}{c}-0.20 \\
(0.14)\end{array}$ & $\begin{array}{c}-0.11 \\
(0.080)\end{array}$ \\
\hline GenToSales & $\begin{array}{c}0.54 \\
(0.43)\end{array}$ & $\begin{array}{c}0.34 \\
(0.25)\end{array}$ & $\begin{array}{c}0.66 \\
(0.54)\end{array}$ & $\begin{array}{c}0.36 \\
(0.29)\end{array}$ & $\begin{array}{l}0.81^{*} \\
(0.44)\end{array}$ & $\begin{array}{l}0.47^{*} \\
(0.27)\end{array}$ \\
\hline $\mathrm{K} / \mathrm{S}$ & $\begin{array}{c}0.15 \\
(0.27)\end{array}$ & $\begin{array}{l}0.087 \\
(0.16)\end{array}$ & $\begin{array}{l}-0.17 \\
(0.28)\end{array}$ & $\begin{array}{c}-0.046 \\
(0.17)\end{array}$ & $\begin{array}{c}-0.39 \\
(0.35)\end{array}$ & $\begin{array}{l}-0.25 \\
(0.21)\end{array}$ \\
\hline $\mathrm{K} / \mathrm{S}$ square & $\begin{array}{c}0.065 \\
(0.085)\end{array}$ & $\begin{array}{c}0.035 \\
(0.053)\end{array}$ & $\begin{array}{c}0.14^{*} \\
(0.085)\end{array}$ & $\begin{array}{c}0.069 \\
(0.056)\end{array}$ & $\begin{array}{c}0.17 \\
(0.10)\end{array}$ & $\begin{array}{c}0.10 \\
(0.062)\end{array}$ \\
\hline $\mathrm{I} / \mathrm{K}$ & $\begin{array}{c}-1.13^{* * *} \\
(0.40)\end{array}$ & $\begin{array}{c}-0.67^{* * *} \\
(0.25)\end{array}$ & $\begin{array}{c}-1.46^{* * *} \\
(0.53)\end{array}$ & $\begin{array}{c}-0.84^{* * *} \\
(0.30)\end{array}$ & $\begin{array}{l}-1.18^{*} \\
(0.67)\end{array}$ & $\begin{array}{l}-0.66^{*} \\
(0.39)\end{array}$ \\
\hline $\mathrm{Y} / \mathrm{S}$ & $\begin{array}{c}-1.42^{* *} \\
(0.63)\end{array}$ & $\begin{array}{c}-1.03^{* * *} \\
(0.36)\end{array}$ & $\begin{array}{c}-1.52^{*} \\
(0.78)\end{array}$ & $\begin{array}{c}-1.09^{* *} \\
(0.43)\end{array}$ & $\begin{array}{l}-1.33 \\
(0.90)\end{array}$ & $\begin{array}{l}-0.96^{*} \\
(0.50)\end{array}$ \\
\hline Leverage & $\begin{array}{l}-0.096 \\
(0.098)\end{array}$ & $\begin{array}{l}-0.046 \\
(0.058)\end{array}$ & $\begin{array}{l}-0.074 \\
(0.11)\end{array}$ & $\begin{array}{l}-0.031 \\
(0.064)\end{array}$ & $\begin{array}{l}-0.16 \\
(0.16)\end{array}$ & $\begin{array}{l}-0.076 \\
(0.091)\end{array}$ \\
\hline Leverage square & $\begin{array}{c}0.011 \\
(0.0092)\end{array}$ & $\begin{array}{c}0.0055 \\
(0.0054)\end{array}$ & $\begin{array}{l}0.0098 \\
(0.010)\end{array}$ & $\begin{array}{c}0.0044 \\
(0.0059)\end{array}$ & $\begin{array}{c}0.016 \\
(0.016)\end{array}$ & $\begin{array}{c}0.0070 \\
(0.0093)\end{array}$ \\
\hline CurrentRatio & $\begin{array}{c}0.61^{* *} \\
(0.31)\end{array}$ & $\begin{array}{l}0.37^{* *} \\
(0.19)\end{array}$ & $\begin{array}{l}0.50^{*} \\
(0.27)\end{array}$ & $\begin{array}{l}0.33^{*} \\
(0.20)\end{array}$ & $\begin{array}{c}0.35 \\
(0.30)\end{array}$ & $\begin{array}{c}0.21 \\
(0.19)\end{array}$ \\
\hline CurrentRatio square & $\begin{array}{c}-0.26^{* *} \\
(0.10)\end{array}$ & $\begin{array}{l}-0.15^{* *} \\
(0.062)\end{array}$ & $\begin{array}{c}-0.22^{* * *} \\
(0.087)\end{array}$ & $\begin{array}{c}-0.14^{* *} \\
(0.068)\end{array}$ & $\begin{array}{l}-0.15 \\
(0.12)\end{array}$ & $\begin{array}{c}-0.088 \\
(0.072)\end{array}$ \\
\hline Constant & $\begin{array}{c}0.71 \\
(0.58)\end{array}$ & $\begin{array}{c}0.43 \\
(0.36)\end{array}$ & $\begin{array}{c}0.92 \\
(0.59)\end{array}$ & $\begin{array}{c}0.52 \\
(0.38)\end{array}$ & $\begin{array}{l}1.09^{*} \\
(0.64)\end{array}$ & $\begin{array}{l}0.66^{*} \\
(0.38)\end{array}$ \\
\hline Year FE & Yes & Yes & Yes & Yes & Yes & Yes \\
\hline Location controls & Yes & Yes & Yes & Yes & Yes & Yes \\
\hline Observations & 135 & 135 & 135 & 135 & 120 & 120 \\
\hline
\end{tabular}

Notes: Table reports detailed estimations of population-averaged GEE model. Dependent variable

is DEA performance score. Semirobust standard errors clustered on firm-level are reported in

parentheses. **** and ${ }^{* * *}$ indicate significance at the 10,5 and 1 percent levels.
Table 8b: Impact of sell-offs on productivity

\begin{tabular}{|c|c|c|c|c|c|c|}
\hline & $\begin{array}{c}(1) \\
\text { Logit }\end{array}$ & $\begin{array}{c}(2) \\
\text { Probit }\end{array}$ & $\begin{array}{c}\text { (3) } \\
\text { Logit }\end{array}$ & $\begin{array}{c}(4) \\
\text { Probit }\end{array}$ & $\begin{array}{l}(5) \\
\text { Logit }\end{array}$ & $\begin{array}{c}(6) \\
\text { Probit }\end{array}$ \\
\hline Seller $\mathrm{t}$ & $\begin{array}{l}-0.072 \\
(0.050)\end{array}$ & $\begin{array}{l}-0.042 \\
(0.030)\end{array}$ & & & & \\
\hline Seller $\mathrm{t}-1$ & & & $\begin{array}{l}-0.015 \\
(0.046)\end{array}$ & $\begin{array}{c}-0.0069 \\
(0.026)\end{array}$ & & \\
\hline Seller $\mathrm{t}-2$ & & & & & $\begin{array}{c}0.062^{* *} \\
(0.029)\end{array}$ & $\begin{array}{c}0.039^{* *} \\
(0.017)\end{array}$ \\
\hline TwoMergers & $\begin{array}{c}0.065 \\
(0.088)\end{array}$ & $\begin{array}{c}0.042 \\
(0.047)\end{array}$ & $\begin{array}{c}0.021 \\
(0.092)\end{array}$ & $\begin{array}{c}0.017 \\
(0.050)\end{array}$ & $\begin{array}{c}0.12 \\
(0.093)\end{array}$ & $\begin{array}{c}0.072 \\
(0.053)\end{array}$ \\
\hline TwoCBMergers & $\begin{array}{l}-0.085 \\
(0.099)\end{array}$ & $\begin{array}{c}-0.053 \\
(0.055)\end{array}$ & $\begin{array}{l}-0.088 \\
(0.099)\end{array}$ & $\begin{array}{l}-0.055 \\
(0.057)\end{array}$ & $\begin{array}{l}-0.21^{*} \\
(0.12)\end{array}$ & $\begin{array}{c}-0.12^{*} \\
(0.068)\end{array}$ \\
\hline GenToSales & $\begin{array}{c}0.60 \\
(0.47)\end{array}$ & $\begin{array}{c}0.35 \\
(0.26)\end{array}$ & $\begin{array}{c}0.63 \\
(0.49)\end{array}$ & $\begin{array}{c}0.35 \\
(0.27)\end{array}$ & $\begin{array}{c}0.71 \\
(0.48)\end{array}$ & $\begin{array}{c}0.42 \\
(0.29)\end{array}$ \\
\hline $\mathrm{K} / \mathrm{S}$ & $\begin{array}{l}-0.10 \\
(0.27)\end{array}$ & $\begin{array}{c}-0.027 \\
(0.17)\end{array}$ & $\begin{array}{c}-0.14 \\
(0.26)\end{array}$ & $\begin{array}{r}-0.037 \\
(0.16)\end{array}$ & $\begin{array}{c}-0.34 \\
(0.29)\end{array}$ & $\begin{array}{c}-0.22 \\
(0.18)\end{array}$ \\
\hline $\mathrm{K} / \mathrm{S}$ square & $\begin{array}{c}0.13 \\
(0.083)\end{array}$ & $\begin{array}{c}0.068 \\
(0.057)\end{array}$ & $\begin{array}{c}0.14^{*} \\
(0.082)\end{array}$ & $\begin{array}{c}0.069 \\
(0.054)\end{array}$ & $\begin{array}{c}0.18^{*} \\
(0.091)\end{array}$ & $\begin{array}{c}0.11^{*} \\
(0.055)\end{array}$ \\
\hline $\mathrm{I} / \mathrm{K}$ & $\begin{array}{c}-1.46^{* * *} \\
(0.47)\end{array}$ & $\begin{array}{c}-0.83^{* * *} \\
(0.29)\end{array}$ & $\begin{array}{c}-1.41^{* * *} \\
(0.54)\end{array}$ & $\begin{array}{c}-0.82^{* * *} \\
(0.30)\end{array}$ & $\begin{array}{l}-1.05 \\
(0.73)\end{array}$ & $\begin{array}{l}-0.60 \\
(0.42)\end{array}$ \\
\hline $\mathrm{Y} / \mathrm{S}$ & $\begin{array}{c}-1.42^{* *} \\
(0.69)\end{array}$ & $\begin{array}{c}-1.03^{* * *} \\
(0.39)\end{array}$ & $\begin{array}{l}-1.47^{*} \\
(0.82)\end{array}$ & $\begin{array}{c}-1.04^{* *} \\
(0.45)\end{array}$ & $\begin{array}{l}-1.26 \\
(0.87)\end{array}$ & $\begin{array}{c}-0.88^{*} \\
(0.50)\end{array}$ \\
\hline Leverage & $\begin{array}{l}-0.077 \\
(0.098)\end{array}$ & $\begin{array}{l}-0.035 \\
(0.058)\end{array}$ & $\begin{array}{l}-0.085 \\
(0.11)\end{array}$ & $\begin{array}{l}-0.037 \\
(0.063)\end{array}$ & $\begin{array}{c}-0.14 \\
(0.13)\end{array}$ & $\begin{array}{l}-0.073 \\
(0.078)\end{array}$ \\
\hline Leverage square & $\begin{array}{c}0.0087 \\
(0.0094)\end{array}$ & $\begin{array}{c}0.0042 \\
(0.0055)\end{array}$ & $\begin{array}{c}0.011 \\
(0.0100)\end{array}$ & $\begin{array}{c}0.0048 \\
(0.0059)\end{array}$ & $\begin{array}{c}0.014 \\
(0.014)\end{array}$ & $\begin{array}{c}0.0064 \\
(0.0083)\end{array}$ \\
\hline CurrentRatio & $\begin{array}{l}0.52^{*} \\
(0.30)\end{array}$ & $\begin{array}{c}0.33 \\
(0.21)\end{array}$ & $\begin{array}{l}0.44^{*} \\
(0.24)\end{array}$ & $\begin{array}{c}0.30 \\
(0.18)\end{array}$ & $\begin{array}{c}0.52 \\
(0.35)\end{array}$ & $\begin{array}{c}0.31 \\
(0.22)\end{array}$ \\
\hline CurrentRatio square & $\begin{array}{l}-0.22^{* *} \\
(0.095)\end{array}$ & $\begin{array}{c}-0.14^{* *} \\
(0.068)\end{array}$ & $\begin{array}{l}-0.20^{* *} \\
(0.080)\end{array}$ & $\begin{array}{l}-0.13^{* *} \\
(0.063)\end{array}$ & $\begin{array}{c}-0.22^{*} \\
(0.13)\end{array}$ & $\begin{array}{c}-0.13 \\
(0.078)\end{array}$ \\
\hline Constant & $\begin{array}{c}0.94 \\
(0.57) \\
\end{array}$ & $\begin{array}{c}0.55 \\
(0.37) \\
\end{array}$ & $\begin{array}{l}0.99^{*} \\
(0.57) \\
\end{array}$ & $\begin{array}{c}0.56 \\
(0.36) \\
\end{array}$ & $\begin{array}{c}0.93 \\
(0.58) \\
\end{array}$ & $\begin{array}{c}0.57 \\
(0.35) \\
\end{array}$ \\
\hline Year FE & Yes & Yes & Yes & Yes & Yes & Yes \\
\hline Location controls & Yes & Yes & Yes & Yes & Yes & Yes \\
\hline Observations & 135 & 135 & 135 & 135 & 120 & 120 \\
\hline
\end{tabular}


Table 9a: Impact of domestic acquisitions on productivity

\begin{tabular}{|c|c|c|c|c|c|c|}
\hline & $\begin{array}{l}(1) \\
\text { Logit }\end{array}$ & $\begin{array}{c}(2) \\
\text { Probit }\end{array}$ & $\begin{array}{c}\text { (3) } \\
\text { Logit }\end{array}$ & $\begin{array}{c}(4) \\
\text { Probit }\end{array}$ & $\begin{array}{l}(5) \\
\text { Logit }\end{array}$ & $\begin{array}{c}(6) \\
\text { Probit }\end{array}$ \\
\hline Domestic buyer $\mathrm{t}$ & $\begin{array}{c}-0.20^{* * *} \\
(0.056)\end{array}$ & $\begin{array}{c}-0.12^{* * *} \\
(0.032)\end{array}$ & & & & \\
\hline Domestic buyer $\mathrm{t}-1$ & & & $\begin{array}{c}0.049 \\
(0.073)\end{array}$ & $\begin{array}{c}0.028 \\
(0.042)\end{array}$ & & \\
\hline Domestic buyer $\mathrm{t}-2$ & & & & & $\begin{array}{c}0.12 \\
(0.080)\end{array}$ & $\begin{array}{c}0.067 \\
(0.047)\end{array}$ \\
\hline TwoMergers & $\begin{array}{c}0.041 \\
(0.085)\end{array}$ & $\begin{array}{c}0.031 \\
(0.045)\end{array}$ & $\begin{array}{c}0.011 \\
(0.100)\end{array}$ & $\begin{array}{c}0.011 \\
(0.054)\end{array}$ & $\begin{array}{c}0.11 \\
(0.10)\end{array}$ & $\begin{array}{c}0.069 \\
(0.059)\end{array}$ \\
\hline TwoCBMergers & $\begin{array}{l}-0.071 \\
(0.092)\end{array}$ & $\begin{array}{c}-0.049 \\
(0.051)\end{array}$ & $\begin{array}{l}-0.086 \\
(0.098)\end{array}$ & $\begin{array}{l}-0.053 \\
(0.056)\end{array}$ & $\begin{array}{c}-0.22^{*} \\
(0.13)\end{array}$ & $\begin{array}{c}-0.12^{*} \\
(0.073)\end{array}$ \\
\hline GenToSales & $\begin{array}{c}0.67 \\
(0.42)\end{array}$ & $\begin{array}{c}0.38 \\
(0.24)\end{array}$ & $\begin{array}{c}0.63 \\
(0.52)\end{array}$ & $\begin{array}{c}0.36 \\
(0.29)\end{array}$ & $\begin{array}{l}0.94^{*} \\
(0.55)\end{array}$ & $\begin{array}{l}0.53^{*} \\
(0.32)\end{array}$ \\
\hline $\mathrm{K} / \mathrm{S}$ & $\begin{array}{c}-0.049 \\
(0.22)\end{array}$ & $\begin{array}{c}-0.00031 \\
(0.13)\end{array}$ & $\begin{array}{l}-0.15 \\
(0.27)\end{array}$ & $\begin{array}{c}-0.054 \\
(0.16)\end{array}$ & $\begin{array}{l}-0.54 \\
(0.35)\end{array}$ & $\begin{array}{l}-0.33 \\
(0.22)\end{array}$ \\
\hline $\mathrm{K} / \mathrm{S}$ square & $\begin{array}{c}0.11 \\
(0.071)\end{array}$ & $\begin{array}{c}0.055 \\
(0.046)\end{array}$ & $\begin{array}{c}0.15^{*} \\
(0.083)\end{array}$ & $\begin{array}{c}0.074 \\
(0.054)\end{array}$ & $\begin{array}{c}0.22^{* *} \\
(0.11)\end{array}$ & $\begin{array}{c}0.13^{*} \\
(0.067)\end{array}$ \\
\hline $\mathrm{I} / \mathrm{K}$ & $\begin{array}{c}-1.51^{* * *} \\
(0.46)\end{array}$ & $\begin{array}{c}-0.82^{* * *} \\
(0.27)\end{array}$ & $\begin{array}{c}-1.37^{* * *} \\
(0.50)\end{array}$ & $\begin{array}{c}-0.80^{* * *} \\
(0.29)\end{array}$ & $\begin{array}{l}-1.19 \\
(0.75)\end{array}$ & $\begin{array}{l}-0.66 \\
(0.42)\end{array}$ \\
\hline $\mathrm{Y} / \mathrm{S}$ & $\begin{array}{c}-1.51^{* *} \\
(0.69)\end{array}$ & $\begin{array}{c}-1.07^{* * *} \\
(0.37)\end{array}$ & $\begin{array}{c}-1.48^{*} \\
(0.78)\end{array}$ & $\begin{array}{c}-1.06^{* *} \\
(0.46)\end{array}$ & $\begin{array}{c}-1.47^{*} \\
(0.88)\end{array}$ & $\begin{array}{c}-1.01^{* *} \\
(0.49)\end{array}$ \\
\hline Leverage & $\begin{array}{l}-0.084 \\
(0.098)\end{array}$ & $\begin{array}{l}-0.041 \\
(0.054)\end{array}$ & $\begin{array}{l}-0.091 \\
(0.100)\end{array}$ & $\begin{array}{l}-0.041 \\
(0.058)\end{array}$ & $\begin{array}{c}-0.13 \\
(0.15)\end{array}$ & $\begin{array}{c}-0.062 \\
(0.086)\end{array}$ \\
\hline Leverage square & $\begin{array}{c}0.0088 \\
(0.0095)\end{array}$ & $\begin{array}{c}0.0045 \\
(0.0052)\end{array}$ & $\begin{array}{c}0.011 \\
(0.0092)\end{array}$ & $\begin{array}{c}0.0052 \\
(0.0053)\end{array}$ & $\begin{array}{c}0.013 \\
(0.016)\end{array}$ & $\begin{array}{c}0.0059 \\
(0.0091)\end{array}$ \\
\hline CurrentRatio & $\begin{array}{c}0.76^{* * *} \\
(0.29)\end{array}$ & $\begin{array}{c}0.47^{* *} \\
(0.20)\end{array}$ & $\begin{array}{l}0.47^{*} \\
(0.26)\end{array}$ & $\begin{array}{c}0.31 \\
(0.20)\end{array}$ & $\begin{array}{c}0.27 \\
(0.27)\end{array}$ & $\begin{array}{c}0.17 \\
(0.17)\end{array}$ \\
\hline CurrentRatio square & $\begin{array}{c}-0.34^{* * *} \\
(0.096)\end{array}$ & $\begin{array}{c}-0.20^{* * *} \\
(0.067)\end{array}$ & $\begin{array}{l}-0.21^{* *} \\
(0.086)\end{array}$ & $\begin{array}{c}-0.13^{* *} \\
(0.068)\end{array}$ & $\begin{array}{c}-0.13 \\
(0.10)\end{array}$ & $\begin{array}{c}-0.079 \\
(0.065)\end{array}$ \\
\hline Constant & $\begin{array}{c}0.72 \\
(0.57) \\
\end{array}$ & $\begin{array}{c}0.43 \\
(0.35) \\
\end{array}$ & $\begin{array}{c}0.94 \\
(0.60) \\
\end{array}$ & $\begin{array}{c}0.53 \\
(0.38) \\
\end{array}$ & $\begin{array}{l}1.12^{*} \\
(0.61) \\
\end{array}$ & $\begin{array}{l}0.68^{*} \\
(0.37) \\
\end{array}$ \\
\hline Year FE & Yes & Yes & Yes & Yes & Yes & Yes \\
\hline Location controls & Yes & Yes & Yes & Yes & Yes & Yes \\
\hline Observations & 135 & 135 & 135 & 135 & 120 & 120 \\
\hline
\end{tabular}

Table 9b: Impact of cross-border acquisitions on productivity

\begin{tabular}{|c|c|c|c|c|c|c|}
\hline & $\begin{array}{c}(1) \\
\text { Logit }\end{array}$ & $\begin{array}{c}(2) \\
\text { Probit }\end{array}$ & $\begin{array}{l}(3) \\
\text { Logit }\end{array}$ & $\begin{array}{c}(4) \\
\text { Probit }\end{array}$ & $\begin{array}{l}\text { (5) } \\
\text { Logit }\end{array}$ & $\begin{array}{c}(6) \\
\text { Probit }\end{array}$ \\
\hline CB buyer $t$ & $\begin{array}{l}-0.11^{*} \\
(0.061)\end{array}$ & $\begin{array}{c}-0.067^{*} \\
(0.036)\end{array}$ & & & & \\
\hline CB buyer $\mathrm{t}-1$ & & & $\begin{array}{c}0.084^{* *} \\
(0.037)\end{array}$ & $\begin{array}{c}0.044^{* *} \\
(0.020)\end{array}$ & & \\
\hline CB buyer $\mathrm{t}-2$ & & & & & $\begin{array}{c}0.12^{*} \\
(0.062)\end{array}$ & $\begin{array}{c}0.061 \\
(0.040)\end{array}$ \\
\hline TwoMergers & $\begin{array}{c}0.064 \\
(0.081)\end{array}$ & $\begin{array}{c}0.037 \\
(0.044)\end{array}$ & $\begin{array}{c}0.00030 \\
(0.089)\end{array}$ & $\begin{array}{l}0.0094 \\
(0.048)\end{array}$ & $\begin{array}{l}0.097 \\
(0.11)\end{array}$ & $\begin{array}{c}0.054 \\
(0.060)\end{array}$ \\
\hline TwoCBMergers & $\begin{array}{l}-0.085 \\
(0.090)\end{array}$ & $\begin{array}{l}-0.049 \\
(0.051)\end{array}$ & $\begin{array}{c}-0.13 \\
(0.093)\end{array}$ & $\begin{array}{l}-0.080 \\
(0.053)\end{array}$ & $\begin{array}{l}-0.18 \\
(0.14)\end{array}$ & $\begin{array}{l}-0.097 \\
(0.079)\end{array}$ \\
\hline GenToSales & $\begin{array}{c}0.54 \\
(0.46)\end{array}$ & $\begin{array}{c}0.34 \\
(0.27)\end{array}$ & $\begin{array}{c}0.67 \\
(0.51)\end{array}$ & $\begin{array}{c}0.36 \\
(0.28)\end{array}$ & $\begin{array}{c}0.73 \\
(0.45)\end{array}$ & $\begin{array}{c}0.44 \\
(0.27)\end{array}$ \\
\hline $\mathrm{K} / \mathrm{S}$ & $\begin{array}{c}0.14 \\
(0.29)\end{array}$ & $\begin{array}{l}0.079 \\
(0.17)\end{array}$ & $\begin{array}{l}-0.16 \\
(0.27)\end{array}$ & $\begin{array}{c}-0.023 \\
(0.16)\end{array}$ & $\begin{array}{c}-0.32 \\
(0.32)\end{array}$ & $\begin{array}{l}-0.22 \\
(0.20)\end{array}$ \\
\hline $\mathrm{K} / \mathrm{S}$ square & $\begin{array}{c}0.067 \\
(0.086)\end{array}$ & $\begin{array}{c}0.037 \\
(0.054)\end{array}$ & $\begin{array}{c}0.14 \\
(0.086)\end{array}$ & $\begin{array}{c}0.064 \\
(0.057)\end{array}$ & $\begin{array}{c}0.15 \\
(0.098)\end{array}$ & $\begin{array}{c}0.093 \\
(0.060)\end{array}$ \\
\hline $\mathrm{I} / \mathrm{K}$ & $\begin{array}{c}-1.08^{* *} \\
(0.42)\end{array}$ & $\begin{array}{c}-0.66^{* *} \\
(0.26)\end{array}$ & $\begin{array}{c}-1.44^{* * *} \\
(0.52)\end{array}$ & $\begin{array}{c}-0.81^{* * *} \\
(0.28)\end{array}$ & $\begin{array}{l}-1.05 \\
(0.67)\end{array}$ & $\begin{array}{c}-0.61 \\
(0.40)\end{array}$ \\
\hline Y/S & $\begin{array}{c}-1.39^{* *} \\
(0.64)\end{array}$ & $\begin{array}{c}-1.02^{* * *} \\
(0.36)\end{array}$ & $\begin{array}{c}-1.33^{*} \\
(0.75)\end{array}$ & $\begin{array}{c}-0.99^{* *} \\
(0.40)\end{array}$ & $\begin{array}{l}-1.15 \\
(0.93)\end{array}$ & $\begin{array}{l}-0.87 \\
(0.53)\end{array}$ \\
\hline Leverage & $\begin{array}{c}-0.10 \\
(0.099)\end{array}$ & $\begin{array}{l}-0.048 \\
(0.058)\end{array}$ & $\begin{array}{c}-0.074 \\
(0.10)\end{array}$ & $\begin{array}{l}-0.031 \\
(0.060)\end{array}$ & $\begin{array}{c}-0.19 \\
(0.16)\end{array}$ & $\begin{array}{l}-0.092 \\
(0.094)\end{array}$ \\
\hline Leverage square & $\begin{array}{c}0.012 \\
(0.0092)\end{array}$ & $\begin{array}{c}0.0057 \\
(0.0054)\end{array}$ & $\begin{array}{c}0.0097 \\
(0.0098)\end{array}$ & $\begin{array}{c}0.0043 \\
(0.0056)\end{array}$ & $\begin{array}{c}0.018 \\
(0.016)\end{array}$ & $\begin{array}{c}0.0082 \\
(0.0094)\end{array}$ \\
\hline CurrentRatio & $\begin{array}{l}0.54^{*} \\
(0.28)\end{array}$ & $\begin{array}{l}0.32^{*} \\
(0.17)\end{array}$ & $\begin{array}{l}0.51^{* *} \\
(0.25)\end{array}$ & $\begin{array}{l}0.34^{*} \\
(0.19)\end{array}$ & $\begin{array}{c}0.25 \\
(0.34)\end{array}$ & $\begin{array}{c}0.16 \\
(0.22)\end{array}$ \\
\hline CurrentRatio square & $\begin{array}{l}-0.23^{* *} \\
(0.090)\end{array}$ & $\begin{array}{l}-0.13^{* *} \\
(0.056)\end{array}$ & $\begin{array}{c}-0.22^{* * *} \\
(0.077)\end{array}$ & $\begin{array}{l}-0.14^{* *} \\
(0.064)\end{array}$ & $\begin{array}{c}-0.11 \\
(0.14)\end{array}$ & $\begin{array}{l}-0.067 \\
(0.083)\end{array}$ \\
\hline Constant & $\begin{array}{c}0.80 \\
(0.55) \\
\end{array}$ & $\begin{array}{c}0.48 \\
(0.35) \\
\end{array}$ & $\begin{array}{c}0.90 \\
(0.56) \\
\end{array}$ & $\begin{array}{c}0.51 \\
(0.36) \\
\end{array}$ & $\begin{array}{l}1.14^{*} \\
(0.64) \\
\end{array}$ & $\begin{array}{l}0.69^{*} \\
(0.39) \\
\end{array}$ \\
\hline Year FE & Yes & Yes & Yes & Yes & Yes & Yes \\
\hline Location controls & Yes & Yes & Yes & Yes & Yes & Yes \\
\hline Observations & 135 & 135 & 135 & 135 & 120 & 120 \\
\hline
\end{tabular}


Table 10a: Impact of domestic sell-offs on productivity

\begin{tabular}{|c|c|c|c|c|c|c|}
\hline & $\begin{array}{l}(1) \\
\text { Logit }\end{array}$ & $\begin{array}{c}(2) \\
\text { Probit }\end{array}$ & $\begin{array}{l}(3) \\
\text { Logit }\end{array}$ & $\begin{array}{c}(4) \\
\text { Probit }\end{array}$ & $\begin{array}{l}(5) \\
\text { Logit }\end{array}$ & $\begin{array}{c}(6) \\
\text { Probit }\end{array}$ \\
\hline Domestic seller t & $\begin{array}{c}-0.12^{* *} \\
(0.054)\end{array}$ & $\begin{array}{c}-0.064^{* *} \\
(0.031)\end{array}$ & & & & \\
\hline Domestic seller $\mathrm{t}-1$ & & & $\begin{array}{l}-0.048 \\
(0.064)\end{array}$ & $\begin{array}{l}-0.028 \\
(0.035)\end{array}$ & & \\
\hline Domestic seller $\mathrm{t}-2$ & & & & & $\begin{array}{c}0.090^{* * * *} \\
(0.028)\end{array}$ & $\begin{array}{c}0.051^{* * *} \\
(0.018)\end{array}$ \\
\hline TwoMergers & $\begin{array}{c}0.052 \\
(0.099)\end{array}$ & $\begin{array}{c}0.036 \\
(0.053)\end{array}$ & $\begin{array}{c}0.029 \\
(0.094)\end{array}$ & $\begin{array}{c}0.021 \\
(0.052)\end{array}$ & $\begin{array}{c}0.11 \\
(0.094)\end{array}$ & $\begin{array}{c}0.067 \\
(0.053)\end{array}$ \\
\hline TwoCBMergers & $\begin{array}{c}-0.094 \\
(0.10)\end{array}$ & $\begin{array}{l}-0.057 \\
(0.056)\end{array}$ & $\begin{array}{l}-0.088 \\
(0.096)\end{array}$ & $\begin{array}{l}-0.054 \\
(0.055)\end{array}$ & $\begin{array}{l}-0.21^{*} \\
(0.12)\end{array}$ & $\begin{array}{l}-0.12^{*} \\
(0.068)\end{array}$ \\
\hline GenToSales & $\begin{array}{c}0.71 \\
(0.49)\end{array}$ & $\begin{array}{c}0.38 \\
(0.27)\end{array}$ & $\begin{array}{c}0.62 \\
(0.49)\end{array}$ & $\begin{array}{c}0.35 \\
(0.28)\end{array}$ & $\begin{array}{c}0.77 \\
(0.50)\end{array}$ & $\begin{array}{c}0.45 \\
(0.29)\end{array}$ \\
\hline $\mathrm{K} / \mathrm{S}$ & $\begin{array}{c}-0.25 \\
(0.25)\end{array}$ & $\begin{array}{c}-0.095 \\
(0.15)\end{array}$ & $\begin{array}{l}-0.13 \\
(0.26)\end{array}$ & $\begin{array}{c}-0.045 \\
(0.16)\end{array}$ & $\begin{array}{c}-0.41 \\
(0.31)\end{array}$ & $\begin{array}{l}-0.25 \\
(0.19)\end{array}$ \\
\hline $\mathrm{K} / \mathrm{S}$ square & $\begin{array}{c}0.16^{* *} \\
(0.075)\end{array}$ & $\begin{array}{l}0.081^{*} \\
(0.048)\end{array}$ & $\begin{array}{c}0.14^{*} \\
(0.081)\end{array}$ & $\begin{array}{c}0.070 \\
(0.053)\end{array}$ & $\begin{array}{c}0.19^{* *} \\
(0.096)\end{array}$ & $\begin{array}{c}0.11^{*} \\
(0.058)\end{array}$ \\
\hline $\mathrm{I} / \mathrm{K}$ & $\begin{array}{c}-1.53^{* * *} \\
(0.55)\end{array}$ & $\begin{array}{c}-0.87^{* * *} \\
(0.30)\end{array}$ & $\begin{array}{c}-1.43^{* * *} \\
(0.52)\end{array}$ & $\begin{array}{c}-0.84^{* * *} \\
(0.30)\end{array}$ & $\begin{array}{l}-1.10 \\
(0.76)\end{array}$ & $\begin{array}{l}-0.64 \\
(0.43)\end{array}$ \\
\hline $\mathrm{Y} / \mathrm{S}$ & $\begin{array}{c}-1.51^{* *} \\
(0.73)\end{array}$ & $\begin{array}{c}-1.04^{* * *} \\
(0.40)\end{array}$ & $\begin{array}{c}-1.49^{*} \\
(0.78)\end{array}$ & $\begin{array}{c}-1.06^{* *} \\
(0.43)\end{array}$ & $\begin{array}{l}-1.37 \\
(0.89)\end{array}$ & $\begin{array}{c}-0.95^{*} \\
(0.51)\end{array}$ \\
\hline Leverage & $\begin{array}{c}-0.10 \\
(0.096)\end{array}$ & $\begin{array}{l}-0.047 \\
(0.054)\end{array}$ & $\begin{array}{c}-0.089 \\
(0.11)\end{array}$ & $\begin{array}{l}-0.039 \\
(0.064)\end{array}$ & $\begin{array}{c}-0.13 \\
(0.13)\end{array}$ & $\begin{array}{l}-0.065 \\
(0.077)\end{array}$ \\
\hline Leverage square & $\begin{array}{c}0.011 \\
(0.0093)\end{array}$ & $\begin{array}{c}0.0049 \\
(0.0054)\end{array}$ & $\begin{array}{c}0.011 \\
(0.010)\end{array}$ & $\begin{array}{c}0.0051 \\
(0.0059)\end{array}$ & $\begin{array}{c}0.012 \\
(0.014)\end{array}$ & $\begin{array}{c}0.0054 \\
(0.0084)\end{array}$ \\
\hline CurrentRatio & $\begin{array}{c}0.31 \\
(0.21)\end{array}$ & $\begin{array}{c}0.21 \\
(0.15)\end{array}$ & $\begin{array}{l}0.45^{*} \\
(0.23)\end{array}$ & $\begin{array}{l}0.29^{*} \\
(0.17)\end{array}$ & $\begin{array}{c}0.45 \\
(0.32)\end{array}$ & $\begin{array}{c}0.27 \\
(0.20)\end{array}$ \\
\hline CurrentRatio square & $\begin{array}{l}-0.15^{* *} \\
(0.064)\end{array}$ & $\begin{array}{c}-0.097^{* *} \\
(0.046)\end{array}$ & $\begin{array}{c}-0.20^{* * *} \\
(0.076)\end{array}$ & $\begin{array}{l}-0.13^{* *} \\
(0.059)\end{array}$ & $\begin{array}{c}-0.19 \\
(0.12)\end{array}$ & $\begin{array}{c}-0.11 \\
(0.073)\end{array}$ \\
\hline Constant & $\begin{array}{l}1.14^{* *} \\
(0.53) \\
\end{array}$ & $\begin{array}{c}0.65^{* *} \\
(0.33) \\
\end{array}$ & $\begin{array}{l}0.99^{*} \\
(0.56) \\
\end{array}$ & $\begin{array}{c}0.57 \\
(0.35) \\
\end{array}$ & $\begin{array}{l}1.00^{*} \\
(0.59) \\
\end{array}$ & $\begin{array}{l}0.61^{*} \\
(0.36) \\
\end{array}$ \\
\hline Year FE & Yes & Yes & Yes & Yes & Yes & Yes \\
\hline Location controls & Yes & Yes & Yes & Yes & Yes & Yes \\
\hline Observations & 135 & 135 & 135 & 135 & 120 & 120 \\
\hline
\end{tabular}

Table 10b: Impact of cross-border sell-offs on productivity

\begin{tabular}{|c|c|c|c|c|c|c|}
\hline & $\begin{array}{c}(1) \\
\text { Logit }\end{array}$ & $\begin{array}{c}(2) \\
\text { Probit }\end{array}$ & $\begin{array}{c}(3) \\
\text { Logit }\end{array}$ & $\begin{array}{c}(4) \\
\text { Probit }\end{array}$ & $\begin{array}{l}\text { (5) } \\
\text { Logit }\end{array}$ & $\begin{array}{c}(6) \\
\text { Probit }\end{array}$ \\
\hline CB seller $\mathrm{t}$ & $\begin{array}{l}0.12^{* *} \\
(0.051)\end{array}$ & $\begin{array}{l}0.067^{*} \\
(0.034)\end{array}$ & & & & \\
\hline CB seller $\mathrm{t}-1$ & & & $\begin{array}{c}0.067 \\
(0.068)\end{array}$ & $\begin{array}{c}0.039 \\
(0.037)\end{array}$ & & \\
\hline CB seller $\mathrm{t}-2$ & & & & & $\begin{array}{l}-0.014 \\
(0.061)\end{array}$ & $\begin{array}{r}-0.0028 \\
(0.036)\end{array}$ \\
\hline TwoMergers & $\begin{array}{l}-0.018 \\
(0.095)\end{array}$ & $\begin{array}{l}-0.0048 \\
(0.054)\end{array}$ & $\begin{array}{c}0.011 \\
(0.083)\end{array}$ & $\begin{array}{c}0.012 \\
(0.046)\end{array}$ & $\begin{array}{l}0.098 \\
(0.11)\end{array}$ & $\begin{array}{c}0.060 \\
(0.060)\end{array}$ \\
\hline TwoCBMergers & $\begin{array}{c}-0.11 \\
(0.091)\end{array}$ & $\begin{array}{l}-0.063 \\
(0.054)\end{array}$ & $\begin{array}{l}-0.085 \\
(0.094)\end{array}$ & $\begin{array}{l}-0.054 \\
(0.054)\end{array}$ & $\begin{array}{l}-0.19 \\
(0.13)\end{array}$ & $\begin{array}{c}-0.11 \\
(0.074)\end{array}$ \\
\hline GenToSales & $\begin{array}{c}0.72 \\
(0.51)\end{array}$ & $\begin{array}{c}0.40 \\
(0.29)\end{array}$ & $\begin{array}{c}0.60 \\
(0.47)\end{array}$ & $\begin{array}{c}0.35 \\
(0.27)\end{array}$ & $\begin{array}{c}0.81 \\
(0.53)\end{array}$ & $\begin{array}{c}0.46 \\
(0.31)\end{array}$ \\
\hline $\mathrm{K} / \mathrm{S}$ & $\begin{array}{l}-0.25 \\
(0.23)\end{array}$ & $\begin{array}{l}-0.12 \\
(0.14)\end{array}$ & $\begin{array}{l}-0.10 \\
(0.26)\end{array}$ & $\begin{array}{c}-0.033 \\
(0.16)\end{array}$ & $\begin{array}{l}-0.43 \\
(0.35)\end{array}$ & $\begin{array}{l}-0.25 \\
(0.21)\end{array}$ \\
\hline $\mathrm{K} / \mathrm{S}$ square & $\begin{array}{c}0.16^{* *} \\
(0.074)\end{array}$ & $\begin{array}{l}0.086^{*} \\
(0.046)\end{array}$ & $\begin{array}{c}0.13 \\
(0.082)\end{array}$ & $\begin{array}{c}0.068 \\
(0.054)\end{array}$ & $\begin{array}{l}0.19^{*} \\
(0.10)\end{array}$ & $\begin{array}{c}0.11^{*} \\
(0.062)\end{array}$ \\
\hline $\mathrm{I} / \mathrm{K}$ & $\begin{array}{c}-1.27^{* *} \\
(0.64)\end{array}$ & $\begin{array}{c}-0.77^{* *} \\
(0.33)\end{array}$ & $\begin{array}{c}-1.26^{* *} \\
(0.51)\end{array}$ & $\begin{array}{c}-0.74^{* *} \\
(0.29)\end{array}$ & $\begin{array}{l}-1.15 \\
(0.80)\end{array}$ & $\begin{array}{l}-0.66 \\
(0.45)\end{array}$ \\
\hline $\mathrm{Y} / \mathrm{S}$ & $\begin{array}{c}-1.54^{* *} \\
(0.76)\end{array}$ & $\begin{array}{c}-1.05^{* * *} \\
(0.40)\end{array}$ & $\begin{array}{c}-1.23^{*} \\
(0.73)\end{array}$ & $\begin{array}{c}-0.92^{* *} \\
(0.40)\end{array}$ & $\begin{array}{l}-1.41 \\
(0.95)\end{array}$ & $\begin{array}{c}-0.96^{*} \\
(0.53)\end{array}$ \\
\hline Leverage & $\begin{array}{l}-0.10 \\
(0.11)\end{array}$ & $\begin{array}{l}-0.047 \\
(0.065)\end{array}$ & $\begin{array}{c}-0.092 \\
(0.11)\end{array}$ & $\begin{array}{l}-0.040 \\
(0.065)\end{array}$ & $\begin{array}{c}-0.12 \\
(0.15)\end{array}$ & $\begin{array}{l}-0.060 \\
(0.088)\end{array}$ \\
\hline Leverage square & $\begin{array}{c}0.013 \\
(0.010)\end{array}$ & $\begin{array}{c}0.0058 \\
(0.0062)\end{array}$ & $\begin{array}{c}0.011 \\
(0.010)\end{array}$ & $\begin{array}{c}0.0051 \\
(0.0060)\end{array}$ & $\begin{array}{c}0.012 \\
(0.016)\end{array}$ & $\begin{array}{c}0.0058 \\
(0.0094)\end{array}$ \\
\hline CurrentRatio & $\begin{array}{c}0.23 \\
(0.22)\end{array}$ & $\begin{array}{c}0.16 \\
(0.17)\end{array}$ & $\begin{array}{l}0.46^{* *} \\
(0.22)\end{array}$ & $\begin{array}{l}0.30^{*} \\
(0.17)\end{array}$ & $\begin{array}{c}0.37 \\
(0.28)\end{array}$ & $\begin{array}{c}0.23 \\
(0.18)\end{array}$ \\
\hline CurrentRatio square & $\begin{array}{c}-0.12 \\
(0.081)\end{array}$ & $\begin{array}{l}-0.082 \\
(0.061)\end{array}$ & $\begin{array}{c}-0.20^{* * *} \\
(0.070)\end{array}$ & $\begin{array}{l}-0.13^{* *} \\
(0.057)\end{array}$ & $\begin{array}{l}-0.17 \\
(0.11)\end{array}$ & $\begin{array}{l}-0.098 \\
(0.066)\end{array}$ \\
\hline Constant & $\begin{array}{l}1.17^{* *} \\
(0.52) \\
\end{array}$ & $\begin{array}{c}0.67^{* *} \\
(0.33) \\
\end{array}$ & $\begin{array}{c}0.92 \\
(0.56) \\
\end{array}$ & $\begin{array}{c}0.53 \\
(0.36) \\
\end{array}$ & $\begin{array}{l}1.05^{*} \\
(0.59) \\
\end{array}$ & $\begin{array}{l}0.64^{*} \\
(0.35) \\
\end{array}$ \\
\hline Year FE & Yes & Yes & Yes & Yes & Yes & Yes \\
\hline Location controls & Yes & Yes & Yes & Yes & Yes & Yes \\
\hline Observations & 135 & 135 & 135 & 135 & 120 & 120 \\
\hline
\end{tabular}




\section{Appendix A. Descriptive statistics and correlations}

Table A1: Descriptive statistics

\begin{tabular}{|c|c|c|c|c|c|c|c|c|}
\hline & Mean & St. Div. & Min & p25 & p50 & p75 & Max & $\mathrm{N}$ \\
\hline \multicolumn{9}{|c|}{ Panel A: DEA input-output variables } \\
\hline Capacity & 39204.3 & 34670.5 & 4500 & 13402 & 32224 & 49582 & 140400 & 135 \\
\hline TOPEX & 31730.3 & 29882.8 & 1607.3 & 8894.5 & 19520.7 & 50066 & 131791.8 & 135 \\
\hline PowerGen & 159.2 & 153.8 & 18.7 & 54.3 & 129.1 & 223.7 & 654 & 135 \\
\hline Emissions & 374.8 & 179.7 & 38 & 244 & 391 & 480 & 866 & 135 \\
\hline \multicolumn{9}{|c|}{ Panel B: Nonfinancial controls } \\
\hline TwoMergers & 0.36 & 0.48 & 0 & 0 & 0 & 1 & 1 & 135 \\
\hline TwoCBMergers & 0.18 & 0.38 & 0 & 0 & 0 & 0 & 1 & 135 \\
\hline GenToSales & 0.77 & 0.20 & 0.32 & 0.63 & 0.78 & 0.88 & 1.29 & 135 \\
\hline \multicolumn{9}{|c|}{ Panel C: Financial controls } \\
\hline $\mathrm{K} / \mathrm{S}$ & 1.29 & 0.60 & 0.35 & 0.72 & 1.30 & 1.70 & 2.98 & 135 \\
\hline $\mathrm{I} / \mathrm{K}$ & 0.12 & 0.067 & 0.029 & 0.079 & 0.10 & 0.14 & 0.42 & 135 \\
\hline $\mathrm{Y} / \mathrm{S}$ & 0.15 & 0.087 & -0.0080 & 0.090 & 0.12 & 0.22 & 0.35 & 135 \\
\hline Leverage & 2.90 & 1.95 & 0.75 & 1.47 & 2.09 & 3.64 & 8.53 & 135 \\
\hline CurrentRatio & 1.10 & 0.24 & 0.51 & 0.95 & 1.08 & 1.21 & 2.10 & 135 \\
\hline
\end{tabular}

Notes: Table reports descriptive statistics. P25, P50 and P75 stand for 25, 50 and 75 percentiles accordingly.

Table A2: Correlation matrix

\begin{tabular}{|c|c|c|c|c|c|c|c|c|c|c|c|c|}
\hline & $\begin{array}{l}\stackrel{\overrightarrow{0}}{\tilde{\sigma}} \\
\tilde{0} \\
\tilde{u}\end{array}$ & 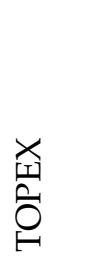 & $\begin{array}{l}5 \\
0 \\
0 \\
0 \\
3 \\
0 \\
0\end{array}$ & 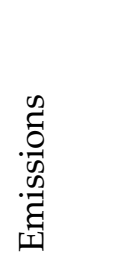 & 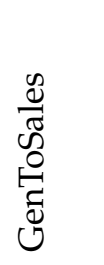 & 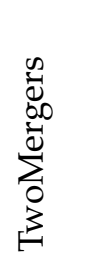 & 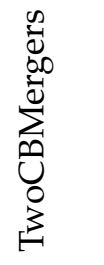 & $\frac{\infty}{v}$ & $\stackrel{\forall}{二}$ & $\stackrel{\infty}{\lambda}$ & 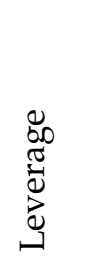 & 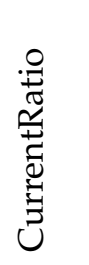 \\
\hline Capacity & 1.00 & & & & & & & & & & & \\
\hline TOPEX & $0.52^{*}$ & 1.00 & & & & & & & & & & \\
\hline PowerGen & $0.97^{*}$ & $0.48^{*}$ & 1.00 & & & & & & & & & \\
\hline Emissions & -0.09 & $0.18^{*}$ & -0.02 & 1.00 & & & & & & & & \\
\hline GenToSales & $0.37^{*}$ & -0.09 & $0.38^{*}$ & -0.03 & 1.00 & & & & & & & \\
\hline TwoMergers & 0.04 & -0.11 & 0.06 & $0.22^{*}$ & 0.11 & 1.00 & & & & & & \\
\hline TwoCBMergers & 0.10 & 0.11 & 0.07 & 0.09 & -0.11 & $0.64^{*}$ & 1.00 & & & & & \\
\hline $\mathrm{K} / \mathrm{S}$ & -0.00 & $-0.55^{*}$ & 0.01 & $-0.51^{*}$ & $0.46^{*}$ & $0.17^{*}$ & -0.00 & 1.00 & & & & \\
\hline $\mathrm{I} / \mathrm{K}$ & -0.15 & $0.37^{*}$ & -0.12 & $0.35^{*}$ & 0.03 & 0.02 & 0.05 & $-0.38^{*}$ & 1.00 & & & \\
\hline $\mathrm{Y} / \mathrm{S}$ & $-0.33^{*}$ & $-0.53^{*}$ & $-0.28^{*}$ & $-0.23^{*}$ & $0.34^{*}$ & $0.20^{*}$ & -0.04 & $0.69^{*}$ & -0.10 & 1.00 & & \\
\hline Leverage & $0.52^{*}$ & 0.13 & $0.55^{*}$ & 0.01 & 0.04 & -0.11 & -0.04 & -0.08 & -0.08 & $-0.31^{*}$ & 1.00 & \\
\hline CurrentRatio & 0.02 & 0.10 & 0.09 & 0.02 & 0.04 & -0.03 & 0.06 & -0.03 & 0.04 & 0.01 & -0.03 & 1.00 \\
\hline
\end{tabular}

Notes: Table reports correlations between DEA components and second-stage control variables. * indicates significance at 5 percent level. 
Figure 3: Correlations between performance and control variables

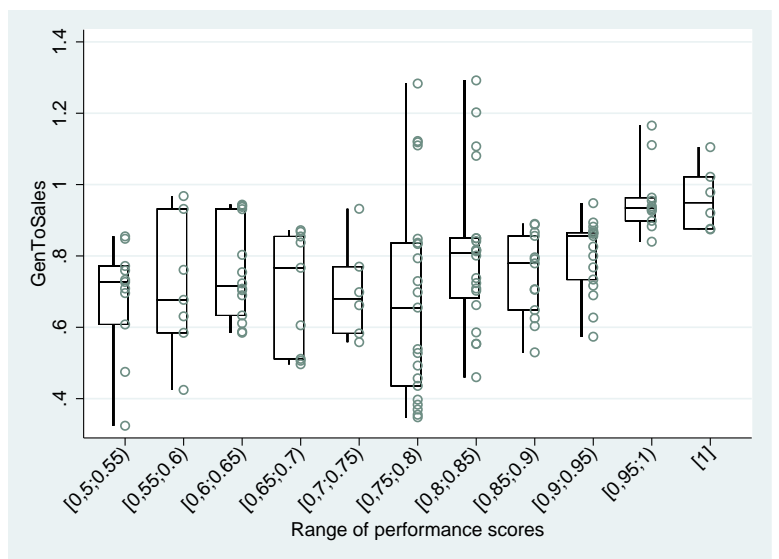

(2.1) GenToSales

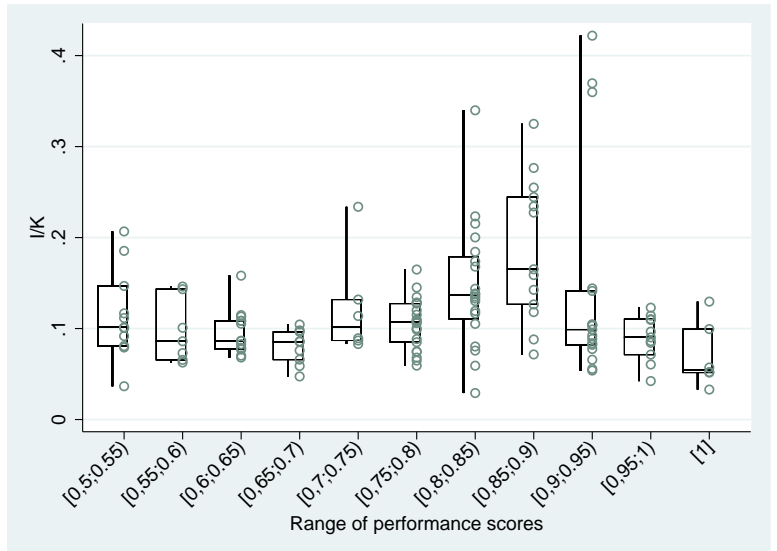

(2.3) I/K

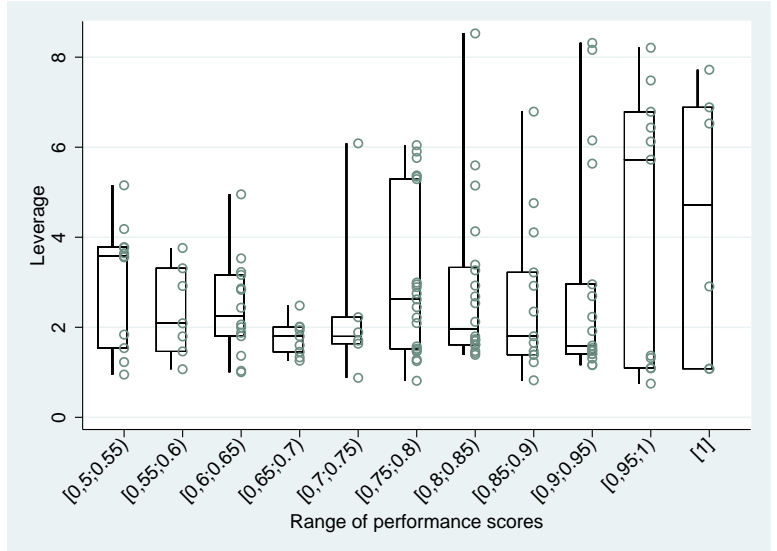

(2.5) Leverage

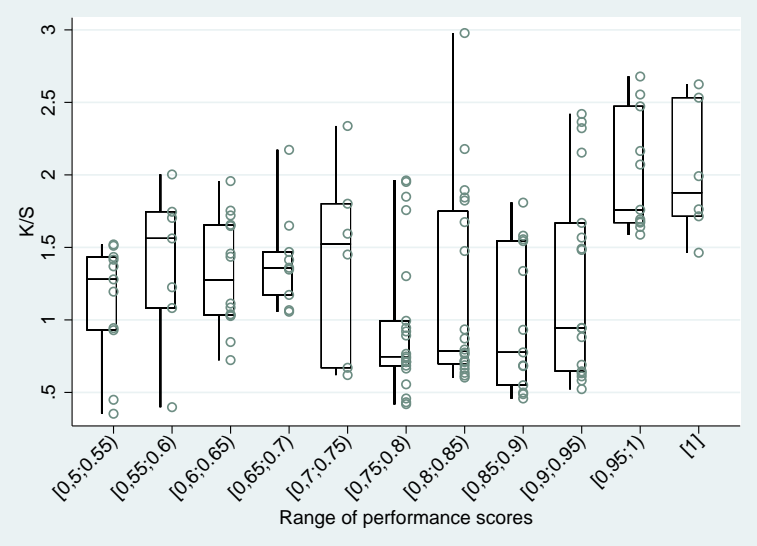

(2.2) $\mathrm{K} / \mathrm{S}$

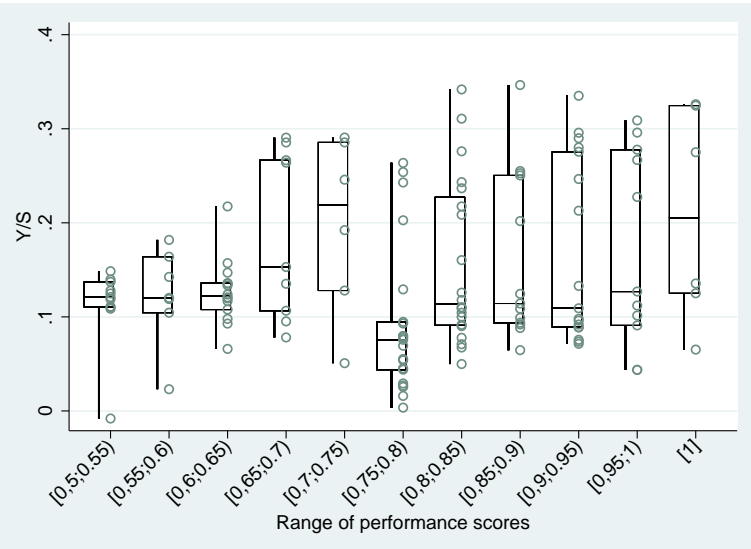

(2.4) $\mathrm{Y} / \mathrm{S}$

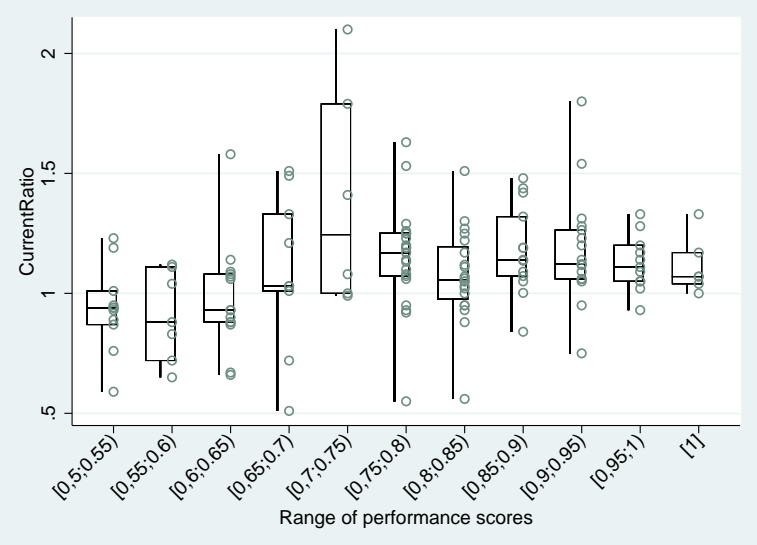

(2.6) CurrentRatio 